\title{
Neurocognitive Development of Motivated Behavior: Dynamic Changes across Childhood and Adolescence
}

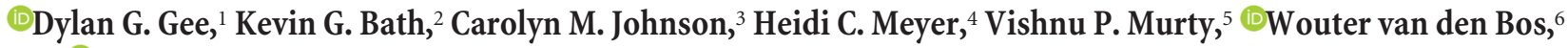 \\ and $\mathbb{C a t h e r i n e ~ A . ~ H a r t l e y ~}^{7}$ \\ ${ }^{1}$ Department of Psychology, Yale University, New Haven, CT 06520, ${ }^{2}$ Department of Cognitive, Linguistic, and Psychological Sciences, Brown University, \\ Providence, RI 02912, ${ }^{3}$ Department of Molecular and Cellular Biology, Harvard University, Cambridge, MA 02138, ${ }^{4}$ Department of Psychiatry, Weill Cornell \\ Medicine, New York, NY 10065, ${ }^{5}$ Department of Psychology, Temple University, Philadelphia, PA 19122, ${ }^{6}$ Department of Developmental Psychology, \\ University of Amsterdam, Amsterdam, Netherlands, and 7Department of Psychology, New York University, New York, NY 10003
}

The ability to anticipate and respond appropriately to the challenges and opportunities present in our environments is critical for adaptive behavior. Recent methodological innovations have led to substantial advances in our understanding of the neurocircuitry supporting such motivated behavior in adulthood. However, the neural circuits and cognitive processes that enable threat- and rewardmotivated behavior undergo substantive changes over the course of development, and these changes are less well understood. In this article, we highlight recent research in human and animal models demonstrating how developmental changes in prefrontal-subcortical neural circuits give rise to corresponding changes in the processing of threats and rewards from infancy to adulthood. We discuss how these developmental trajectories are altered by experiential factors, such as early-life stress, and highlight the relevance of this research for understanding the developmental onset and treatment of psychiatric disorders characterized by dysregulation of motivated behavior.

Key words: motivation; threat; reward; development; early life stress; prefrontal cortex; dopamine

\section{Introduction}

The past decades have seen a surge in research on the neurocircuitry supporting motivated behavior in adulthood. Convergent findings across species suggest that dynamic interaction between the prefrontal cortex (PFC) and subcortical regions, including the amygdala, hippocampus, and striatum, plays a central role in learning to predict potential threats and rewards and determining how to respond to such environmental challenges (Phelps and LeDoux, 2005; Haber and Knutson, 2010; Stuber et al., 2011; Namburi et al., 2015; Beyeler et al., 2016; Burgos-Robles et al., 2017). At the same time, a convergent literature has elucidated pronounced changes in the structure and function of these circuits from childhood to adulthood (Murty et al., 2016; Casey et al., 2017), highlighting the protracted development of structural connections between the PFC and subcortical regions (BarneaGoraly et al., 2005; Lebel et al., 2012; Simmonds et al., 2014; Achterberg et al., 2016), as well as shifting functional dynamics within this circuitry (Gee et al., 2013b; Betzel et al., 2014; Swartz

Received Aug. 9, 2018; revised Sept. 23, 2018; accepted Sept. 24, 2018.

D.G.G. was supported by National Institutes of Health Director's Early Independence Award DP50D021370, National Institute of Mental Health R61 Grant R61MH115113, and Brain and Behavior Research Foundation Young Investigator Grant. C.A.H. was supported by a Klingenstein-Simons Fellowship Award, National Science Foundation Career Grant 1654393, Brain and Behavior Research Foundation Young Investigator Grant, and Jacobs Foundation Early Career Fellowship.

The authors declare no competing financial interests.

Correspondence should be addressed to either of the following: Dr. Dylan G. Gee, Department of Psychology, Yale University, 2 Hillhouse Avenue, New Haven, CT 06520, E-mail: dylan.gee@yale.edu; or Dr. Catherine A. Hartley, Department of Psychology, New York University, 6 Washington Place, New York, NY 10003, E-mail: cate@nyu.edu.

https://doi.org/10.1523/JNEUROSCl.1674-18.2018

Copyright $\odot 2018$ the authors $\quad 0270-6474 / 18 / 389433-13 \$ 15.00 / 0$ et al., 2014; Fareri et al., 2015; Jalbrzikowski et al., 2017). These findings are consistent with the marked changes in motivated learning and decision-making that occur across development; however, to date, we have only a provisional understanding of how these behavioral changes relate to developmental changes in the brain.

In this review, we present recent research that has begun to elucidate both neural and cognitive mechanisms that give rise to shifts in threat and reward processing from childhood to adulthood. Building on an extensive literature on aversive conditioning and extinction in humans and animal models in adulthood, we first discuss how the neurocognitive processes that underpin threat prediction and reactive behavioral responses to anticipated threats change over the course of development. In light of extensive evidence for the central role of dopamine (DA) in the modulation of many facets of reward processing, we next discuss how developmental changes in the dopaminergic system across adolescence might relate to changes in reward-motivated behavior during this developmental period (Fig. 1). The threats an individual may face and the experiences that they deem rewarding will vary as a function of developmental stage, as well as across individuals. Just as motivated behavior may shift to meet the needs of a particular developmental challenge, alterations in the species-expected environment may demand adaptations in motivated behavior. In the third section of this review, we emphasize how changes in motivated behavior over the course of development may represent experience-dependent adaptations to the demands of one's environment or developmental stage, and discuss how atypical experiences (e.g., exposure to early-life stress) might alter the normative developmental trajectory of motivated 

Infancy

\section{Genes Early-life stress $\quad$ Pubertal hormones}
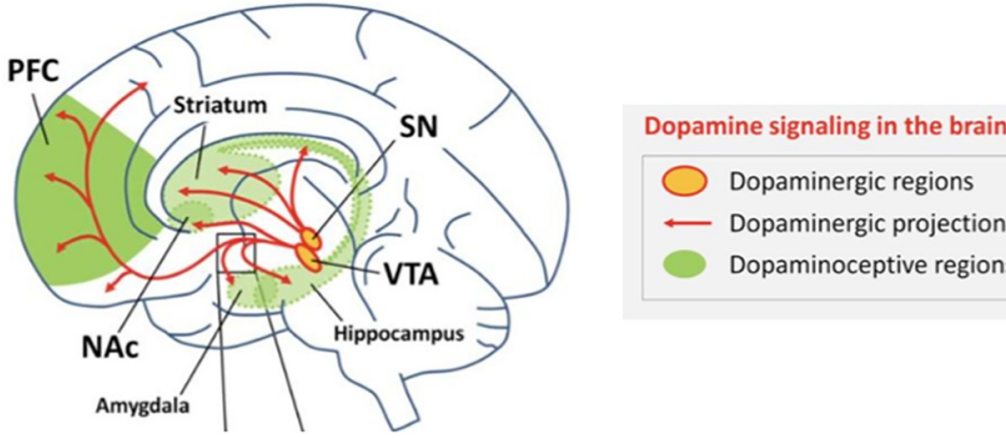

Dopaminergic regions

Dopaminergic projections

Dopaminoceptive regions

\section{Changes in threat- and reward-motivated behavior}

Psychopathology

Figure 1. Neurocognitive development of motivated behavior. Prefrontal-subcortical circuitry and dopaminergic signaling undergo profound changes across childhood and adolescence (prefrontal cortex, PFC; nucleus accumbens, NAc; substantia nigra, SN; ventral tegmental area, VTA). These changes can interact with, and be influenced by, biological and environmental factors to alter trajectories of threat- and reward-motivated behavior in ways that alter risk for the emergence of psychopathology. Circuitry diagram adapted with permission from Sinclair et al. (2014).

behavior. Childhood and adolescence are periods of increased risk for psychiatric disorders (Kessler et al., 2007; Paus et al., 2008), the majority of which are characterized by core deficits in the ability to accurately anticipate and respond adaptively to potential threats and rewards. In the final section, we highlight how alterations in the normative trajectory of prefrontal-subcortical circuitry and motivated behavior may contribute to risk for psychiatric disorders at specific developmental stages and the implications of this research for optimizing clinical interventions during development.

\section{Neurocircuitry of threat processing and its development}

The ability to learn that cues or contexts signal potential threat, and to modify these learned associations as the environment changes, is critical for adaptive function. These abilities and their underlying neural mechanisms develop over time. Studies in rodents and humans have yielded a detailed model of the neurocircuitry underlying the acquisition and extinction of aversive learning in adulthood (Hartley and Phelps, 2010; Milad and Quirk, 2012). This work highlights the central role of the amygdala in acquisition, storage, and maintenance of aversive learning (Fanselow and LeDoux, 1999; Maren and Quirk, 2004), whereas extinction learning and retention involve dynamic interactions between the amygdala, the infralimbic (IL) and prelimbic (PL) regions of PFC, and the hippocampus (Maren and Quirk, 2004; Sierra-Mercado et al., 2011). Specifically, during adulthood, reciprocal connections between the amygdala and PL (for which the dorsal anterior cingulate is the proposed human homolog) drive the expression of conditioned responses to threat, and their reciprocal connections with the IL (for which the ventromedial PFC is the proposed human homolog) can inhibit the expression of conditioned responses to threat (Sotres-Bayon and Quirk, 2010). Mature rodents and humans show robust aversive learning, including avoidance, freezing, and elevated physiologi- cal reactivity to stimuli that have been paired with shock (e.g., Blanchard and Blanchard, 1969; Bolles and Collier, 1976). In adulthood, the extinction of conditioned responses is subject to relapse (i.e., the return of conditioned responding even after extinction) through renewal, reinstatement, and spontaneous recovery (e.g., Bouton, 2002). These forms of relapse indicate that, in mature animals, the aversive memory is not forgotten, even if the behavioral expression of fear has been attenuated.

Consistent with marked changes in prefrontal-subcortical circuitry, aversive learning undergoes substantial change across childhood and adolescence. Aversive conditioned responses are largely suppressed in young rat pups, before postnatal day (PND) 10 (Rudy and Cheatle, 1977), although the ability to feel pain and detect an aversive stimulus are both intact (Stehouwer and Campbell, 1978; Collier and Bolles, 1980; Emerich et al., 1985; Barr, 1995). Unlike avoidance or freezing behaviors observed in adults, pups exhibit approach behaviors toward odors that have been paired with a shock (Camp and Rudy, 1988; Sullivan et al., 2000). These findings have been taken to reflect a dominance of infant-caregiver attachment learning early in life (Landers and Sullivan, 2012), consistent with the role of maternal presence in suppressing rat pups' aversive learning until approximately PND 15 (Stanton et al., 1987; Suchecki et al., 1993; Moriceau and Sullivan, 2006). Following PND 10 and coinciding with the capacity for learning-induced synaptic plasticity in the amygdala, rats gain the ability to acquire aversive conditioned responses when not in the presence of the mother (Thompson et al., 2008; Landers and Sullivan, 2012). During the juvenile stage of development, although PL activity increases in response to aversive conditioned stimuli, inactivation of PL does not attenuate conditioned responding until adolescence (Monk, 2008; Chan et al., 2011; Li et al., 2012). Moreover, the inverse activity of PL and IL that is observed in adult aversive learning and regulation (Gilmartin 
and McEchron, 2005; Corcoran and Quirk, 2007; Quirk and Mueller, 2008) emerges after the juvenile period (Kim et al., 2009).

In both humans and rodents, memories for aversive associations acquired during infancy (before PND 18 in rodents) are not as robust or persistent as those acquired later in life and are susceptible to forgetting through a process known as infantile amnesia (Campbell and Campbell, 1962; Campbell and Spear, 1972; Hayne, 2004; Kim and Richardson, 2007; Josselyn and Frankland, 2012; Li et al., 2014; Mullally and Maguire, 2014; Alberini and Travaglia, 2017). Moreover, during the juvenile stage, extinction learning is not subject to the forms of relapse typically observed in adults (renewal, reinstatement, and spontaneous recovery), suggesting that extinction learning during this stage may yield "unlearning" or erasure of the original aversive association (Yap and Richardson, 2007; Gogolla et al., 2009; Kim et al., 2009). The closing of this window for memory erasure through extinction coincides with changes in extracellular matrix chondroitin sulfate proteoglycans within the juvenile amygdala after which aversive memories are protected from erasure by perineuronal nets (Gogolla et al., 2009; Duvarci and Pare, 2014), as well as hippocampal-dependent changes mediating the closure of the window for infantile amnesia (Alberini and Travaglia, 2017).

During adolescence, aversive learning appears to be persistently retained and easily generalized (Morrow et al., 1969; Hefner and Holmes, 2007; McCallum et al., 2010; Kim et al., 2011; Pattwell et al., 2012; D. C. Johnson and Casey, 2015a; Baker et al., 2016). Adolescent rodents exhibit diminished extinction learning relative to younger and older individuals (McCallum et al., 2010; Kim et al., 2011; Pattwell et al., 2012), with impaired retention of extinction memory also apparent during adolescence in rats (McCallum et al., 2010; Kim et al., 2011; Baker and Richardson, 2015). Protracted development of prefrontal regions (PL and IL), which continues well into adolescence (Giedd et al., 1996, 1999; Cunningham et al., 2002; Gogtay et al., 2004; Casey et al., 2005; Chan et al., 2011), may limit the capacity for prefrontal regulation of the amygdala and hippocampus. Indeed, amygdala potentiation is observed following cued aversive conditioning during adolescence in mice (Pattwell et al., 2011; Saul et al., 2014). Interestingly, connectivity between the amygdala and PL is stronger in adolescence than in preadolescence or adulthood, marked by an increased number of axonal projections and a surge in dendritic spine formation in PL (Pattwell et al., 2016). As a result, a positive feedback loop may be maintained in this circuit that mediates the persistent expression of conditioned responses. Although the amygdala appears to be similarly involved in extinction across development, in rats, IL is not required for extinction before PND 21 (Kim et al., 2009). This suggests a change in the connectivity between amygdala and IL that emerges later in development (Arruda-Carvalho et al., 2017) to support adult-like, extinction learning. Moreover, bidirectional PL-amygdala synapses mature earlier than IL-amygdala synapses (Chan et al., 2011), and adolescent rodents exhibit blunted IL activity during extinction (Pattwell et al., 2012; Cruz et al., 2015), suggesting potential neurobiological mechanisms underlying the resistance of conditioned responses to extinction during adolescence.

Relative to cued conditioning, contextual conditioning in rodents emerges later in development (Rudy, 1992, 1993; McCallum et al., 2010; Pattwell et al., 2011; Schiffino et al., 2011; Jablonski et al., 2012; Akers et al., 2014). This developmental trajectory parallels the protracted maturation of the hippocampus (Raineki et al., 2010; Akers et al., 2014), consistent with its central role in the processing of contextual information (Maren et al., 2013). Despite intact contextual conditioning in preadoles- cents, freezing in a conditioned context is suppressed during adolescence (Pattwell et al., 2011). This developmental difference is likely due to a temporary inability to retrieve, rather to encode, the contextual aversive memory during adolescence because mice are able to retrieve and express the contextual aversive memory as they transition out of adolescence and into adulthood, coinciding with an increase in basal amygdala activity (Pattwell et al., 2011). Moreover, even previously consolidated aversive memories acquired during the juvenile period are temporarily suppressed during adolescence.

Research on aversive learning during human infancy and childhood has been more limited; however, consistent with evidence in rodents, humans exhibit substantial changes in aversive learning across development. Aversive learning has been observed soon after birth, with both infants (Wickens and Wickens, 1940; Ingram and Fitzgerald, 1974) and toddlers (Gao et al., 2010) exhibiting extinction and relapse effects. However, responding to aversive conditioned stimuli increases across childhood (Gao et al., 2010; Glenn et al., 2012; Jovanovic et al., 2014; Michalska et al., 2016) and differs between adolescents and adults (Lau et al., 2011), suggesting that the underlying aversive learning process continues to mature. As in rodents, the adolescent period in humans is marked by diminished extinction learning relative to younger and older individuals (Pattwell et al., 2012; D. C. Johnson and Casey, 2015b).

Consistent with changes in behavior, the neural circuitry underlying aversive learning in humans also undergoes developmental changes. The amygdala exhibits early structural (Humphrey, 1968; Giedd et al., 1996; Ulfig et al., 2003; Payne et al., 2010) and functional (Graham et al., 2016; Rogers et al., 2017; Gabard-Durnam et al., 2018) maturation; however, its functioning shifts across human development (Hare et al., 2008; Decety et al., 2012; Gee et al., 2013b; Swartz et al., 2014; Vink et al., 2014; Silvers et al., 2015). The amygdala responds differentially to threat cues as early as infancy in humans (Graham et al., 2013). Although aversive learning depends primarily on the amygdala early in life, a more complex circuit, including the hippocampus and PFC, supports aversive learning later in human development (Lau et al., 2011; Britton et al., 2013), consistent with a similar shift in rodents (Kim et al., 2009; Li et al., 2012). Moreover, the processes by which threat reactivity is regulated change by developmental stage. As with rodents, caregivers play a central role in suppressing threat reactivity early in life when regulatory connections are still maturing. Specifically, in humans, parental presence reduces the hypothalamic-pituitary-adrenal axis response and amygdala reactivity to stress during childhood (Gunnar and Donzella, 2002; Ahnert et al., 2004; Feldman et al., 2010; Seltzer et al., 2012; Gee et al., 2014; Hostinar et al., 2014), but not during adolescence (Gee et al., 2014; Hostinar et al., 2015). Despite diminished extinction learning in adolescence, longer-term reduction of conditioned responding is achieved when methods rely less on the PFC (e.g., extinction during memory reconsolidation, at which time a reactivated memory can be updated), than with PFC-dependent methods (e.g., extinction) (D. C. Johnson and Casey, 2015b). These findings correspond with continued development of connectivity between the hippocampus, amygdala, and PFC across childhood and adolescence in humans, both structurally (Lebel et al., 2012; Swartz et al., 2014; Gee et al., 2016) and functionally (Perlman and Pelphrey, 2011; Decety et al., 2012; Qin et al., 2012; Gee et al., 2013b; Gabard-Durnam et al., 2014; Vink et al., 2014; Jalbrzikowski et al., 2017).

While this section focused primarily on developmental changes in the acquisition and extinction of Pavlovian reactive 
responses, a more recent literature in adult humans and animal models has begun to characterize the neurocognitive processes involved in the learning of threat-motivated instrumental actions that are effective at preventing aversive outcomes (LeDoux and Daw, 2018). Functional integration between the amygdala, striatum, and PFC appears to be critically involved in such active avoidance learning (Moscarello and LeDoux, 2013; Bravo-Rivera et al., 2014; Collins et al., 2014; Boeke et al., 2017; Diehl et al., 2018). An important area of future study will be to elucidate how changes within this circuitry modulate the learning and expression of threat-motivated instrumental actions across development.

\section{Neurocircuitry of reward processing and its development}

Convergent evidence in adult humans and animal models indicates a central role for the DA system in reward processing. DA neurons project broadly throughout the striatum, PFC, hippocampus, and the amygdala, and exhibit heterogeneity in receptor types and cotransmitters, conferring diverse mechanisms for influencing motivated behavior (Lammel et al., 2014; Hu, 2016). Consistent with this complex organization, DA has been implicated in a broad array of reward-related processes in adulthood, including learning the value of stimuli and actions (Schultz, 2015), determining how much time, effort, or risk-taking is warranted for a potential outcome (Salamone and Correa, 2012), and modulating memory for reward-associated events (Shohamy and Adcock, 2010).

The DA system also undergoes significant changes across development (Teicher et al., 1995; Galván, 2013; Spear, 2013). Although findings are somewhat mixed (Galván, 2013), evidence in rodents suggests that DA receptor binding and tonic DA concentrations within the striatum, a region centrally implicated in reward learning (Haber and Knutson, 2010), peak in adolescence (Tarazi et al., 1998; Badanich et al., 2006; Philpot et al., 2009). Corroborating these findings in animals, DA receptor density in the striatum is highest in postmortem adolescent human brains, relative to postmortem child and adult brains (Haycock et al., 2003), and adolescents exhibit greater striatal engagement during reward processing than children and adults in neuroimaging studies (Silverman et al., 2015). Notably, the adolescent peak in DA availability and reward-related activation is paralleled by typical adolescent behaviors, such as increased exploration, noveltyseeking, and risk-taking in both primates and rodents (Laviola et al., 2003; Spear, 2013), as well as changes in many laboratory measures of reward-related learning and decision-making (Hartley and Somerville, 2015). However, at present, we lack a clear mechanistic understanding of how developmental changes in DA signaling across adolescence alter reward processing.

The activity of DA neurons has been observed to closely approximate a reward prediction error (RPE) signal, a fundamental reward learning computation that encodes when rewards exceed or fall short of one's current expectation (Schultz et al., 1997). Striatal activity correlating with RPE signals has been observed from childhood onwards in several neuroimaging studies (Galvan et al., 2006; van den Bos et al., 2012; Keren et al., 2018). These signals likely support the early-developing ability to associate cues and actions with their reward values, which is evident from the earliest stages of postnatal development (Johanson and Hall, 1979). Although many studies have shown enhanced striatal responses to reward in adolescence (Silverman et al., 2015), and some find that RPE signals are specifically enhanced (Cohen et al., 2010) and associated with better learning performance (Peters and Crone, 2017) during this period, this pattern has not been observed consistently across reward learning tasks (van den Bos et al., 2012; Christakou et al., 2013). Thus, the significance of adolescents' increased striatal sensitivity to reward for learning remains unclear.

Dopaminergic networks extending beyond the striatum also contribute to reward processing. Bidirectional projections connect DA nuclei with the PFC and hippocampus, which enable DA signaling to be modulated by current goals and environmental features (e.g., novelty) to which the hippocampus and PFC are sensitive (Goto and Grace, 2005; Sesack and Grace, 2010). These connections between DA neurons with the PFC and hippocampus also facilitate functions, such as working memory, attention, and episodic memory (Seamans and Yang, 2004; Shohamy and Adcock, 2010). Projections from DA nuclei to the striatum can organize corticothalamic circuits (Haber, 2003), providing a mechanism by which reward signals can guide higher-order learning and decision-making (Balleine and O'Doherty, 2010; Botvinick, 2012). To date, the developmental trajectories of this broader circuitry remain poorly characterized. However, the hippocampus and PFC have protracted maturation into early adulthood (Giedd, 2004; Ghetti and Bunge, 2012) and exhibit changes in the excitation-inhibition balance during adolescence that suggest ongoing refinement of the function of these circuits (O’Donnell, 2010; Luna et al., 2015; Gomes et al., 2016).

Recent studies have begun to characterize the development of behaviors that require integration across these prefrontalstriatal-hippocampal circuits by administering more complex tasks that require learning more than simple reward associations. These studies suggest that the use of structured knowledge to explore or plan how best to obtain current or future rewards (van den Bos et al., 2015; Decker et al., 2016; Somerville et al., 2018), and the use of counterfactual reward information to guide choices (Palminteri et al., 2016), increase gradually from childhood into young adulthood. This gradual developmental emergence is consistent with evidence that these cognitive processes are PFC-dependent in adults (Daw et al., 2011; Badre et al., 2012; Donoso et al., 2014) and with the protracted development of prefrontal-subcortical connectivity (Casey et al., 2016).

Notably, other aspects of reward learning appear to be facilitated in adolescence relative to adulthood. A recent study found that adolescents showed better learning in a probabilistic reward learning task, and that their episodic memory for rewarding outcomes was related to heightened hippocampal RPE signals and greater functional connectivity between the hippocampus and the striatum during reward receipt (Davidow et al., 2016). This finding is consistent with recent suggestions that the functional development of the DA system during adolescence, through its projections to both the striatum and the hippocampus, may facilitate memory for reward-associated experiences during this period (Murty et al., 2016). These early studies provide burgeoning evidence of developmental changes in reward processing across multiple learning systems, and suggest that network integration between the striatum, PFC, and hippocampus across development contributes to these shifts in learning and decisionmaking. This work underscores the need for further research regarding the relationship between the myriad changes in adolescents' reward-motivated behavior and the function of these neural circuits, and examining the mediating role of DA systems.

Accumulating evidence suggests that pubertal hormones are also important modulators of adolescent reward processing. Indeed, several studies in humans have reported a positive relationship between pubertal testosterone and risk-taking (Forbes et al., 2010; Op de Macks et al., 2011; Cardoos et al., 2017) and impulsivity (Laube et al., 2017). Moreover, recent studies have found that activation in the ventral striatum was positively correlated 
with salivary testosterone (Op de Macks et al., 2011; Braams et al., 2015), suggesting that there may be direct modulation of DA pathways by pubertal hormones. However, this hypothesis is only partially supported by findings in the animal literature. For instance, pubertal changes in gonadal hormones do not play a role in adolescent DA receptor overproduction (Andersen et al., 2002). Moreover, animal studies primarily identify the dorsal, not ventral, striatum as a key target of pubertal hormones (Matthews et al., 2013; Sinclair et al., 2014; Laube and van den Bos, 2016). In addition, these studies show that increases in pubertal hormones typically lead to a decrease in DA function (Stamford, 1989; Matthews et al., 2013; Purves-Tyson et al., 2014). Given the robust connectivity of the dorsal striatum to the PFC, it is possible that the influence of pubertal hormones on DA signaling specifically affects prefrontal influence over reward processing. Thus, while many details remain unclear, the extant animal literature suggests that pubertal hormones do impact the DA pathway. An important open question is how this hormonal modulation of DA in adolescence specifically influences reward processing and motivation.

Future research will be essential for establishing a mechanistic understanding of the ways in which specific developmental changes in prefrontal-striatal-hippocampal circuitry and DA signaling influence the changes in reward processing that characterize transitions from childhood to adulthood.

\section{Effects of early-life stress on threat and reward processing}

The early postnatal period sets the foundation for socioemotional and cognitive development. Elevated neuroplasticity renders the young brain exquisitely sensitive to environmental stimuli, such that early experiences can have lifelong effects on corticalsubcortical circuitry and behavior (McEwen, 2003; Hensch, 2005; Lupien et al., 2009; Shonkoff et al., 2012). Early in life, stable and responsive caregiving is one of the strongest species-expected experiences for altricial mammals (Tottenham, 2012). Caregiveroffspring relationships are essential for normative brain and behavioral development, rendering disruptions of early caregiving a profound stressor (Tottenham, 2012; Kok et al., 2015; McLaughlin et al., 2015; Bernier et al., 2016; Callaghan and Tottenham, 2016a; Gee, 2016). Even relatively brief alterations in caregiving have been associated with deleterious long-term physical and mental health outcomes (Heim and Nemeroff, 2001; Sánchez et al., 2001; Anda et al., 2006; Zeanah et al., 2009; Conti et al., 2012).

In humans, early-life adversity has been associated with myriad cognitive and socioemotional impairments, including reduced cognitive functioning (Nelson et al., 2007), delayed academic performance (Loman et al., 2009), alterations in associative learning (Hanson et al., 2017; Kamkar et al., 2017; Sheridan et al., 2018), and deficits in cognitive flexibility, working memory, and behavioral inhibition (Richards and Wadsworth, 2004; Bos et al., 2009; McDermott et al., 2012; Hanson et al., 2013; Harms et al., 2018). In the socioemotional domain, early-life stress is associated with social dysfunction, anxiety and depressive symptoms, and reduced ability to suppress attention to potential threat in favor of goal-directed behavior (Tottenham et al., 2010, 2011; Lawler et al., 2014; Burkholder et al., 2016; Krugers et al., 2017; Sheridan et al., 2018). These effects are mediated by altered patterns of neural structure, function, and connectivity in prefrontal-subcortical circuitry (Edmiston et al., 2011; Gee et al., 2013a; Hanson et al., 2013; Herringa et al., 2013; Bick et al., 2015; Thomason et al., 2015; Chen and Baram, 2016; Teicher et al., 2016; Fareri et al., 2017; Kaiser et al., 2018), which has a high density of glucocorticoid receptors (Woolley et al., 1990; Honkaniemi et al., 1992; De Kloet et al., 1998; Plotsky et al., 2005; Lupien et al., 2009; Wang et al., 2014). Changes in volume of the PFC, hippocampus, and amygdala have been identified following early-life stress (Mehta et al., 2009; Tottenham et al., 2010; van Harmelen et al., 2010; Luby et al., 2013; Hanson et al., 2015; Hodel et al., 2015; McLaughlin et al., 2016), and these alterations are associated with depression and anxiety symptoms (Vythilingam et al., 2002; Frodl et al., 2010; Tottenham et al., 2010; Bick et al., 2017). In parallel to structural changes, early-life stress drives altered patterns of brain activation, with evidence for hypoactivation in the PFC, hippocampus, and ventral striatum (Mehta et al., 2010; Goff et al., 2013; van Harmelen et al., 2014; Liberzon et al., 2015; Hanson et al., 2016), and hyperactivation in the amygdala (Tottenham et al., 2011; Gee et al., 2013a).

Given ethical considerations that preclude the direct manipulation of the early childhood environment in humans, animal models have provided insight into the causal relationship between early-life stress and long-term behavioral, anatomical, neurochemical, and hormonal changes. Rodents exposed to early-life stress display similar behavioral phenotypes as those observed in humans, including alterations in cognitive functioning and responding to threat and reward. More specifically, rodent studies have demonstrated consequences of early-life stress that include deficits in working memory (Brenhouse and Andersen, 2011; Yang et al., 2015; Grassi-Oliveira et al., 2016), altered reward processing (Fuentes et al., 2018), reduced cognitive flexibility (Powell et al., 2015; Thomas et al., 2016), increased anxiety-like behavior (Kalinichev et al., 2002; Romeo et al., 2003), and altered social behavior (Kikusui and Mori, 2009).

As in humans, early-life stress in rodents leads to long-term changes in prefrontal-subcortical circuitry. Early-life stress or repeated stimulation of the hypothalamic-pituitary-adrenal-axis through pharmacological means is associated with diminished cell proliferation and increased cell death in the hippocampus (Gould et al., 1991a, b, 1992; Dachir et al., 1993; Cameron and Gould, 1994; Gould et al., 1997, 1998; Gage et al., 1998; Tanapat et al., 1998) and dendritic arbor atrophy and decreased dendritic spine plasticity in the hippocampus and PFC (Woolley et al., 1990; Watanabe et al., 1992; Magariños et al., 1998; Chen et al., 2008; Liston and Gan, 2011; Chen et al., 2013; Yang et al., 2015). Recent evidence suggests that early-life stress may alter the typical trajectory of adolescent PFC synapse overproduction and pruning (C. M. Johnson et al., 2016) to prematurely limit plasticity. In addition, several studies indicate reductions in PFC parvalbumin protein or cell labeling (Brenhouse and Andersen, 2011; Holland et al., 2014; Powell et al., 2015; Grassi-Oliveira et al., 2016), although results vary depending on the timing and duration of the stress paradigm, sex of the animal, and subregion of the PFC. Amygdala connectivity, structure, and function are also altered by early-life stress in rodents (Caldji et al., 2000; Sabatini et al., 2007; Malter Cohen et al., 2013; Yan et al., 2017; F. K. Johnson et al., 2018), yielding amygdala hyperactivity that persists even after termination of the stressor and the maturation of PFC, paralleling observations in humans (Malter Cohen et al., 2013).

Given evidence that early-life stress can shift the timing of prefrontal-subcortical development, the "stress acceleration hypothesis" posits that early-life stress leads to the accelerated development of neural and behavioral trajectories for aversive learning (e.g., Callaghan and Tottenham, 2016b). Rodents exposed to early-life stress exhibit accelerated development of the hippocampus (i.e., earlier maturation of parvalbumin interneurons, precocious synaptic development, and earlier onset of my- 
elination) and earlier emergence of the inhibition of contextual conditioned responding (Bath et al., 2016). Similarly, early-life stress in rodents is followed by accelerated trajectories of cued conditioning (Sullivan et al., 2000; Moriceau et al., 2009; Callaghan and Richardson, 2011; Cowan et al., 2013) that have been associated with precocious engagement of the basolateral amygdala during the acquisition of aversive learning (Moriceau et al., 2004; Moriceau and Sullivan, 2006). Earlier structural maturation of the amygdala (Ono et al., 2008) and PFC (Muhammad et al., 2012) are also associated with early-life stress in rodents. In humans, early-life stress is followed by earlier emergence of adult-like functional connectivity between the amygdala and PFC (Gee et al., 2013a) and the recruitment of broader hippocampal-amygdala-PFC circuitry during aversive learning (Silvers et al., 2016). Paralleling findings in rodents (Moriceau et al., 2004, 2006), the earlier maturation of frontoamygdala circuitry in humans was mediated by cortisol levels (Gee et al., 2013a), suggesting that early-life stress may accelerate prefrontalsubcortical development via modifications of the hypothalamicpituitary-adrenal axis (e.g., Ruttle et al., 2015). Changes in the timing of circuit maturation may confer initial benefits as an ontogenetic adaptation to meet the needs of the developing organism in an adverse environment (e.g., Gee et al., 2013a); however, there are likely to be long-term consequences of altered developmental timing. Moreover, much remains unknown about the nature of alterations in timing, such as whether they reflect acceleration to an adult-like state or premature closure of a sensitive period in development.

Alterations in prefrontal-subcortical circuit development likely play an important mediating role in the pathway from early-life stress to later psychopathology (Green et al., 2010; Kessler et al., 2010). Importantly, behavioral and clinical phenotypes following early-life stress can vary across individuals and domains of functioning (e.g., Rutter and O'Connor, 2004). The nature of stress exposure (e.g., Sheridan and McLaughlin, 2014) and its timing relative to specific sensitive periods of neuroplasticity (e.g., Tottenham and Sheridan, 2009; Gee and Casey, 2015) may be critical determinants of long-term effects. Future research will be essential to delineate the dimensions of stress exposure and neurobiological and environmental factors that promote risk versus resilience following early-life stress.

\section{Clinical implications}

Deficits in motivated behavior are core features of psychiatric disorders, including depression, anxiety, bipolar disorder, schizophrenia, and substance use disorders. Each of these disorders is characterized by alterations in the capacity to appropriately predict and respond to threats or rewards in the environment (e.g., Dillon et al., 2014). Such deficits are consistent with observed abnormalities in prefrontal-subcortical circuitry across many forms of psychopathology (Rauch et al., 2003; Casey et al., 2007; Monk, 2008; Goldstein and Volkow, 2011; Arnsten and Rubia, 2012; Taylor et al., 2012; Brotman et al., 2014; Heller, 2016; J. A. Johnston et al., 2017) and with evidence that effective treatments act on this same circuitry (Goldapple et al., 2004; Ressler and Mayberg, 2007; Goldin et al., 2013).

The majority of psychiatric disorders emerge before adulthood (Kessler et al., 2007). Understanding neurodevelopmental changes in prefrontal-subcortical circuitry and their role in both the emergence of illness onset as well as treatment efficacy is critical to reducing the substantial burden of psychiatric disorders. The developing brain may be particularly vulnerable to certain forms of psychopathology at specific maturational stages. As one example, 1 in 5 adolescents has a psychiatric disorder that will persist into adulthood (Kessler et al., 2005). The confluence of neurodevelopmental state, hormonal changes and puberty, changes in stress reactivity (Romeo et al., 2006; Foilb et al., 2011), and increases in social demands may render adolescents particularly vulnerable to disruption in reward- or threat-motivated behavior (Ernst et al., 2009; Casey et al., 2016). Heightened sensitivity to rewards, increases in novelty-seeking, and enhanced exploratory behavior during adolescence are likely to serve adaptive functions, in part promoting transitions to adult roles. However, individual differences that predispose certain adolescents to vulnerability may interact with this developmental stage in ways that increase risk for disorders, such as substance use (e.g., Chambers et al., 2003), depression (e.g., Silberg et al., 1999), and anxiety (e.g., Gee et al., 2016).

The biological state of the brain at distinct developmental stages may have direct implications for optimizing treatments for these disorders in children and adolescents. Although the majority of treatments for youth are based on research in adults, pronounced changes during brain development suggest that mechanisms of illness and treatment are likely to vary across the lifespan (Lee et al., 2014). Integrating the neuroscience of the developing brain and motivated behavior with research on clinical interventions may enhance treatment outcomes during development. For example, in the domain of pediatric anxiety disorders, evidence-based treatments, such as cognitivebehavioral therapy and selective serotonin reuptake inhibitors, have proven effective (e.g., Walkup et al., 2008), yet recent studies highlight the need for enhanced clinical efficacy (e.g., Ginsburg et al., 2018). Protracted development of the regulatory connections between the PFC and amygdala may constrain mechanisms of anxiety reduction during childhood or adolescence (e.g., Pattwell et al., 2012), suggesting potential avenues to optimize interventions via approaches that are less dependent on the PFC (e.g., D. C. Johnson and Casey, 2015b). Future research that aims to optimize treatment based on the developing brain and state of threat- and reward-motivated behavior in childhood and adolescence may be especially useful for informing the timing and types of intervention that will be most effective at specific developmental stages.

In conclusion, dynamic changes in prefrontal-subcortical circuitry across childhood and adolescence support the development of motivated behavior. Unique developmental stages require individuals to flexibly respond and adapt to distinct environmental challenges and opportunities. Cross-species evidence demonstrates that experiential inputs actively shape the development of prefrontal-subcortical circuitry, and stress early in life can influence the structure, function, and maturational timing of this circuitry. Alterations in prefrontal-subcortical interactions likely contribute to deviations from the normative developmental trajectory of motivated behavior and confer risk for the myriad psychiatric disorders characterized by deficits in threat and reward processing. Future investigations that focus on elucidating brain-behavior relationships across development will be essential to understanding how prefrontal-subcortical maturation drives the development of motivated behavior and informing interventions that target deficits in threat- and reward-motivated behavior at specific developmental stages in psychopathology.

\section{References}

Achterberg M, Peper JS, van Duijvenvoorde AC, Mandl RC, Crone EA (2016) Frontostriatal white matter integrity predicts development of de- 
lay of gratification: a longitudinal study. J Neurosci 36:1954-1961. CrossRef Medline

Ahnert L, Gunnar MR, Lamb ME, Barthel M (2004) Transition to child care: associations with infant-mother attachment, infant negative emotion, and cortisol elevations. Child Dev 75:639-650. CrossRef Medline

Akers KG, Martinez-Canabal A, Restivo L, Yiu AP, De Cristofaro A, Hsiang HL, Wheeler AL, Guskjolen A, Niibori Y, Shoji H, Ohira K, Richards BA, Miyakawa T, Josselyn SA, Frankland PW (2014) Hippocampal neurogenesis regulates forgetting during adulthood and infancy. Science 344: 598-602. CrossRef Medline

Alberini CM, Travaglia A (2017) Infantile amnesia: a critical period of learning to learn and remember. J Neurosci 37:5783-5795. CrossRef Medline

Anda RF, Felitti VJ, Bremner JD, Walker JD, Whitfield C, Perry BD, Dube SR, Giles WH (2006) The enduring effects of abuse and related adverse experiences in childhood. Eur Arch Psychiatry Clin Neurosci 256:174-186. CrossRef Medline

Andersen SL, Thompson AP, Krenzel E, Teicher MH (2002) Pubertal changes in gonadal hormones do not underlie adolescent dopamine receptor overproduction. Psychoneuroendocrinology 27:683-691. CrossRef Medline

Arnsten AF, Rubia K (2012) Neurobiological circuits regulating attention, cognitive control, motivation, and emotion: disruptions in neurodevelopmental psychiatric disorders. J Am Acad Child Adolesc Psychiatry 51: 356-367. CrossRef Medline

Arruda-Carvalho M, Wu WC, Cummings KA, Clem RL (2017) Optogenetic examination of prefrontal-amygdala synaptic development. J Neurosci 37:2976-2985. CrossRef Medline

Badanich KA, Adler KJ, Kirstein CL (2006) Adolescents differ from adults in cocaine conditioned place preference and cocaine-induced dopamine in the nucleus accumbens septi. Eur J Pharmacol 550:95-106. CrossRef Medline

Badre D, Doll BB, Long NM, Frank MJ (2012) Rostrolateral prefrontal cortex and individual differences in uncertainty-driven exploration. Neuron 73:595-607. CrossRef Medline

Baker KD, Richardson R (2015) Forming competing fear learning and extinction memories in adolescence makes fear difficult to inhibit. Learn Mem 22:537-543. CrossRef Medline

Baker KD, Bisby MA, Richardson R (2016) Impaired fear extinction in adolescent rodents: behavioural and neural analyses. Neurosci Biobehav Rev 70:59-73. CrossRef Medline

Balleine BW, O’Doherty JP (2010) Human and rodent homologies in action control: corticostriatal determinants of goal-directed and habitual action. Neuropsychopharmacology 35:48-69. CrossRef Medline

Barnea-Goraly N, Menon V, Eckert M, Tamm L, Bammer R, Karchemskiy A, Dant CC, Reiss AL (2005) White matter development during childhood and adolescence: a cross-sectional diffusion tensor imaging study. Cereb Cortex 15:1848-1854. CrossRef Medline

Barr GA (1995) Ontogeny of nociception and antinociception. NIDA Res Monogr 158:172-201. Medline

Bath KG, Manzano-Nieves G, Goodwill H (2016) Early life stress accelerates behavioral and neural maturation of the hippocampus in male mice. Horm Behav 82:64-71. CrossRef Medline

Bernier A, Calkins SD, Bell MA (2016) Longitudinal associations between the quality of mother-infant interactions and brain development across infancy. Child Dev 87:1159-1174. CrossRef Medline

Betzel RF, Byrge L, He Y, Goñi J, Zuo XN, Sporns O (2014) Changes in structural and functional connectivity among resting-state networks across the human lifespan. Neuroimage 102:345-357. CrossRef Medline

Beyeler A, Namburi P, Glober GF, Simonnet C, Calhoon GG, Conyers GF, Luck R, Wildes CP, Tye KM (2016) Divergent routing of positive and negative information from the amygdala during memory retrieval. Neuron 90:348-361. CrossRef Medline

Bick J, Zhu T, Stamoulis C, Fox NA, Zeanah C, Nelson CA (2015) Effect of early institutionalization and foster care on long-term white matter development: a randomized clinical trial. JAMA Pediatr 169:211-219. CrossRef Medline

Bick J, Fox N, Zeanah C, Nelson CA (2017) Early deprivation, atypical brain development, and internalizing symptoms in late childhood. Neuroscience 342:140-153. CrossRef Medline

Blanchard RJ, Blanchard DC (1969) Crouching as an index of fear. J Comp Physiol Psychol 67:370-375. CrossRef Medline

Boeke EA, Moscarello JM, LeDoux JE, Phelps EA, Hartley CA (2017) Active avoidance: neural mechanisms and attenuation of Pavlovian conditioned responding. J Neurosci 37:4808-4818. CrossRef Medline

Bolles RC, Collier AC (1976) The effect of predictive cues on freezing in rats. Anim Learn Behav 4:6-8. CrossRef

Bos KJ, Fox N, Zeanah CH, Nelson CA III (2009) Effects of early psychosocial deprivation on the development of memory and executive function. Front Behav Neurosci 3:16. CrossRef Medline

Botvinick MM (2012) Hierarchical reinforcement learning and decision making. Curr Opin Neurobiol 22:956-962. CrossRef Medline

Bouton ME (2002) Context, ambiguity, and unlearning: sources of relapse after behavioral extinction. Biol Psychiatry 52:976-986. CrossRef Medline

Braams BR, van Duijvenvoorde AC, Peper JS, Crone EA (2015) Longitudinal changes in adolescent risk-taking: a comprehensive study of neural responses to rewards, pubertal development, and risk-taking behavior. J Neurosci 35:7226-7238. CrossRef Medline

Bravo-Rivera C, Roman-Ortiz C, Brignoni-Perez E, Sotres-Bayon F, Quirk GJ (2014) Neural structures mediating expression and extinction of platformmediated avoidance. J Neurosci 34:9736-9742. CrossRef Medline

Brenhouse HC, Andersen SL (2011) Nonsteroidal anti-inflammatory treatment prevents delayed effects of early life stress in rats. Biol Psychiatry 70:434-440. CrossRef Medline

Britton JC, Grillon C, Lissek S, Norcross MA, Szuhany KL, Chen G, Ernst M, Nelson EE, Leibenluft E, Shechner T, Pine DS (2013) Response to learned threat: an FMRI study in adolescent and adult anxiety. Am J Psychiatry 170:1195-1204. CrossRef Medline

Brotman MA, Tseng WL, Olsavsky AK, Fromm SJ, Muhrer EJ, Rutenberg JG, Deveney CM, Adleman NE, Zarate CA, Pine DS, Leibenluft E (2014) Fronto-limbic-striatal dysfunction in pediatric and adult patients with bipolar disorder: impact of face emotion and attentional demands. Psychol Med 44:1639-1651. CrossRef Medline

Burgos-Robles A, Kimchi EY, Izadmehr EM, Porzenheim MJ, Ramos-Guasp WA, Nieh EH, Felix-Ortiz AC, Namburi P, Leppla CA, Presbrey KN, Anandalingam KK, Pagan-Rivera PA, Anahtar M, Beyeler A, Tye KM (2017) Amygdala inputs to prefrontal cortex guide behavior amid conflicting cues of reward and punishment. Nat Neurosci 20:824-835. CrossRef Medline

Burkholder AR, Koss KJ, Hostinar CE, Johnson AE, Gunnar MR (2016) Early life stress: effects on the regulation of anxiety expression in children and adolescents. Soc Dev 25:777-793. CrossRef Medline

Caldji C, Francis D, Sharma S, Plotsky PM, Meaney MJ (2000) The effects of early rearing environment on the development of $\mathrm{GABA}_{\mathrm{A}}$ and central benzodiazepine receptor levels and novelty-induced fearfulness in the rat. Neuropsychopharmacology 22:219-229. CrossRef Medline

Callaghan BL, Richardson R (2011) Maternal separation results in early emergence of adult-like fear and extinction learning in infant rats. Behav Neurosci 125:20-28. CrossRef Medline

Callaghan BL, Tottenham N (2016a) The neuro-environmental loop of plasticity: a cross-species analysis of parental effects on emotion circuitry development following typical and adverse caregiving. Neuropsychopharmacology 41:163-176. CrossRef Medline

Callaghan BL, Tottenham N (2016b) The stress acceleration hypothesis: effects of early-life adversity on emotion circuits and behavior. Curr Opin Behav Sci 7:76-81. CrossRef Medline

Cameron HA, Gould E (1994) Adult neurogenesis is regulated by adrenal steroids in the dentate gyrus. Neuroscience 61:203-209. CrossRef Medline

Camp LL, Rudy JW (1988) Changes in the categorization of appetitive and aversive events during postnatal development of the rat. Dev Psychobiol 21:25-42. CrossRef Medline

Campbell BA, Campbell EH (1962) Retention and extinction of learned fear in infant and adult rats. J Comp Physiol Psychol 55:1-8. CrossRef Medline

Campbell BA, Spear NE (1972) Ontogeny of memory. Psychol Rev 79:215236. CrossRef Medline

Cardoos SL, Ballonoff Suleiman A, Johnson M, van den Bos W, Hinshaw SP, Dahl RE (2017) Social status strategy in early adolescent girls: testosterone and value-based decision making. Psychoneuroendocrinology 81: 14-21. CrossRef Medline

Casey BJ, Tottenham N, Liston C, Durston S (2005) Imaging the developing brain: what have we learned about cognitive development? Trends Cogn Sci 9:104-110. CrossRef Medline

Casey BJ, Epstein JN, Buhle J, Liston C, Davidson MC, Tonev ST, Spicer J, 
Niogi S, Millner AJ, Reiss A, Garrett A, Hinshaw SP, Greenhill LL, Shafritz KM, Vitolo A, Kotler LA, Jarrett MA, Glover G (2007) Frontostriatal connectivity and its role in cognitive control in parent-child dyads with ADHD. Am J Psychiatry 164:1729-1736. CrossRef Medline

Casey BJ, Galván A, Somerville LH (2016) Beyond simple models of adolescence to an integrated circuit-based account: a commentary. Dev Cogn Neurosci 17:128-130. CrossRef Medline

Casey BJ, Heller AS, Gee DG, Cohen AO (2017) Development of the emotional brain. Neurosci Lett. Advance online publication. Retrieved Dec. 1, 2017. doi: 10.1016/j.neulet.2017.11.055. CrossRef Medline

Chambers RA, Taylor JR, Potenza MN (2003) Developmental neurocircuitry of motivation in adolescence: a critical period of addiction vulnerability. Am J Psychiatry 160:1041-1052. CrossRef Medline

Chan T, Kyere K, Davis BR, Shemyakin A, Kabitzke PA, Shair HN, Barr GA, Wiedenmayer CP (2011) The role of the medial prefrontal cortex in innate fear regulation in infants, juveniles, and adolescents. J Neurosci 31:4991-4999. CrossRef Medline

Chen Y, Baram TZ (2016) Toward understanding how early-life stress reprograms cognitive and emotional brain networks. Neuropsychopharmacology 41:197-206. CrossRef Medline

Chen Y, Dubé CM, Rice CJ, Baram TZ (2008) Rapid loss of dendritic spines after stress involves derangement of spine dynamics by corticotropinreleasing hormone. J Neurosci 28:2903-2911. CrossRef Medline

Chen Y, Kramár EA, Chen LY, Babayan AH, Andres AL, Gall CM, Lynch G, Baram TZ (2013) Impairment of synaptic plasticity by the stress mediator $\mathrm{CRH}$ involves selective destruction of thin dendritic spines via RhoA signaling. Mol Psychiatry 18:485-496. CrossRef Medline

Christakou A, Gershman SJ, Niv Y, Simmons A, Brammer M, Rubia K (2013) Neural and psychological maturation of decision-making in adolescence and young adulthood. J Cogn Neurosci 25:1807-1823. CrossRef Medline

Cohen JR, Asarnow RF, Sabb FW, Bilder RM, Bookheimer SY, Knowlton BJ, Poldrack RA (2010) A unique adolescent response to reward prediction errors. Nat Neurosci 13:669-671. CrossRef Medline

Collier AC, Bolles RC (1980) The ontogenesis of defensive reactions to shock in preweanling rats. Dev Psychobiol 13:141-150. CrossRef Medline

Collins KA, Mendelsohn A, Cain CK, Schiller D (2014) Taking action in the face of threat: neural synchronization predicts adaptive coping. J Neurosci 34:14733-14738. CrossRef Medline

Conti G, Hansman C, Heckman JJ, Novak MF, Ruggiero A, Suomi SJ (2012) Primate evidence on the late health effects of early-life adversity. Proc Natl Acad Sci U S A 109:8866-8871. CrossRef Medline

Corcoran KA, Quirk GJ (2007) Activity in prelimbic cortex is necessary for the expression of learned, but not innate, fears. J Neurosci 27:840-844. CrossRef Medline

Cowan CS, Callaghan BL, Richardson R (2013) Acute early-life stress results in premature emergence of adult-like fear retention and extinction relapse in infant rats. Behav Neurosci 127:703-711. CrossRef Medline

Cruz E, Soler-Cedeño O, Negrón G, Criado-Marrero M, Chompré G, Porter JT (2015) Infralimbic EphB2 modulates fear extinction in adolescent rats. J Neurosci 35:12394-12403. CrossRef Medline

Cunningham MG, Bhattacharyya S, Benes FM (2002) Amygdalo-cortical sprouting continues into early adulthood: implications for the development of normal and abnormal function during adolescence. J Comp Neurol 453:116-130. CrossRef Medline

Dachir S, Kadar T, Robinzon B, Levy A (1993) Cognitive deficits induced in young rats by long-term corticosterone administration. Behav Neural Biol 60:103-109. CrossRef Medline

Davidow JY, Foerde K, Galván A, Shohamy D (2016) An upside to reward sensitivity: the hippocampus supports enhanced reinforcement learning in adolescence. Neuron 92:93-99. CrossRef Medline

Daw ND, Gershman SJ, Seymour B, Dayan P, Dolan RJ (2011) Model-based influences on humans' choices and striatal prediction errors. Neuron 69:1204-1215. CrossRef Medline

Decety J, Michalska KJ, Kinzler KD (2012) The contribution of emotion and cognition to moral sensitivity: a neurodevelopmental study. Cereb Cortex 22:209-220. CrossRef Medline

Decker JH, Otto AR, Daw ND, Hartley CA (2016) From creatures of habit to goal-directed learners: tracking the developmental emergence of modelbased reinforcement learning. Psychol Sci 27:848-858. CrossRef Medline

De Kloet ER, Vreugdenhil E, Oitzl MS, Joëls M (1998) Brain corticosteroid receptor balance in health and disease. Endocr Rev 19:269-301. CrossRef Medline

Diehl MM, Bravo-Rivera C, Rodriguez-Romaguera J, Pagan-Rivera PA, Burgos-Robles A, Roman-Ortiz C, Quirk GJ (2018) Active avoidance requires inhibitory signaling in the rodent prelimbic prefrontal cortex. eLife 7:e34657. CrossRef Medline

Dillon DG, Rosso IM, Pechtel P, Killgore WD, Rauch SL, Pizzagalli DA (2014) Peril and pleasure: an rdoc-inspired examination of threat responses and reward processing in anxiety and depression. Depress Anxiety 31:233-249. CrossRef Medline

Donoso M, Collins AG, Koechlin E (2014) Human cognition. foundations of human reasoning in the prefrontal cortex. Science 344:1481-1486. CrossRef Medline

Duvarci S, Pare D (2014) Amygdala microcircuits controlling learned fear. Neuron 82:966-980. CrossRef Medline

Edmiston EE, Wang F, Mazure CM, Guiney J, Sinha R, Mayes LC, Blumberg HP (2011) Corticostriatal-limbic gray matter morphology in adolescents with self-reported exposure to childhood maltreatment. Arch Pediatr Adolesc Med 165:1069-1077. CrossRef Medline

Emerich DF, Scalzo FM, Enters EK, Spear NE, Spear LP (1985) Effects of 6-hydroxydopamine-induced catecholamine depletion on shockprecipitated wall climbing of infant rat pups. Dev Psychobiol 18:215-227. CrossRef Medline

Ernst M, Romeo RD, Andersen SL (2009) Neurobiology of the development of motivated behaviors in adolescence: a window into a neural systems model. Pharmacol Biochem Behav 93:199-211. CrossRef Medline

Fanselow MS, LeDoux JE (1999) Why we think plasticity underlying Pavlovian fear conditioning occurs in the basolateral amygdala. Neuron 23: 229-232. CrossRef Medline

Fareri DS, Gabard-Durnam L, Goff B, Flannery J, Gee DG, Lumian DS, Caldera C, Tottenham N (2015) Normative development of ventral striatal resting state connectivity in humans. Neuroimage 118:422-437. CrossRef Medline

Fareri DS, Gabard-Durnam L, Goff B, Flannery J, Gee DG, Lumian DS, Caldera C, Tottenham N (2017) Altered ventral striatal-medial prefrontal cortex resting-state connectivity mediates adolescent social problems after early institutional care. Dev Psychopathol 29:1865-1876. CrossRef Medline

Feldman R, Singer M, Zagoory O (2010) Touch attenuates infants' physiological reactivity to stress. Dev Sci 13:271-278. CrossRef Medline

Foilb AR, Lui P, Romeo RD (2011) The transformation of hormonal stress responses throughout puberty and adolescence. J Endocrinol 210:391398. CrossRef Medline

Forbes EE, Ryan ND, Phillips ML, Manuck SB, Worthman CM, Moyles DL, Tarr JA, Sciarrillo SR, Dahl RE (2010) Healthy adolescents' neural response to reward: associations with puberty, positive affect, and depressive symptoms. J Am Acad Child Adolesc Psychiatry 49:162-172.e1-5. Medline

Frodl T, Reinhold E, Koutsouleris N, Reiser M, Meisenzahl EM (2010) Interaction of childhood stress with hippocampus and prefrontal cortex volume reduction in major depression. J Psychiatr Res 44:799-807. CrossRef Medline

Fuentes S, Carrasco J, Hatto A, Navarro J, Armario A, Monsonet M, Ortiz J, Nadal R (2018) Sex-dependent impact of early-life stress and adult immobilization in the attribution of incentive salience in rats. PLoS One 13:e0190044. CrossRef Medline

Gabard-Durnam LJ, Flannery J, Goff B, Gee DG, Humphreys KL, Telzer E, Hare T, Tottenham N (2014) The development of human amygdala functional connectivity at rest from 4 to 23 years: a cross-sectional study. Neuroimage 95:193-207. CrossRef Medline

Gabard-Durnam LJ, O'Muircheartaigh J, Dirks H, Dean DC 3rd, Tottenham N, Deoni S (2018) Human amygdala functional network development: a cross-sectional study from 3 months to 5 years of age. Dev Cogn Neurosci 34:63-74. CrossRef Medline

Gage FH, Kempermann G, Palmer TD, Peterson DA, Ray J (1998) Multipotent progenitor cells in the adult dentate gyrus. J Neurobiol 36:249-266. CrossRef Medline

Galván A (2013) The teenage brain: sensitivity to rewards. Curr Dir Psychol Sci 22:88-93. CrossRef

Galvan A, Hare TA, Parra CE, Penn J, Voss H, Glover G, Casey BJ (2006) Earlier development of the accumbens relative to orbitofrontal cortex 
might underlie risk-taking behavior in adolescents. J Neurosci 26:68856892. CrossRef Medline

Gao Y, Raine A, Venables PH, Dawson ME, Mednick SA (2010) The development of skin conductance fear conditioning in children from ages 3 to 8 years. Dev Sci 13:201-212. CrossRef Medline

Gee DG (2016) Sensitive periods of emotion regulation: influences of parental care on frontoamygdala circuitry and plasticity. New Dir Child Adolesc Dev 2016:87-110. CrossRef Medline

Gee DG, Casey BJ (2015) The impact of developmental timing for stress and recovery. Neurobiol Stress 1:184-194. CrossRef Medline

Gee DG, Gabard-Durnam LJ, Flannery J, Goff B, Humphreys KL, Telzer EH, Hare TA, Bookheimer SY, Tottenham N (2013a) Early developmental emergence of human amygdala-prefrontal connectivity after maternal deprivation. Proc Natl Acad Sci U S A 110:15638-15643. CrossRef Medline

Gee DG, Humphreys KL, Flannery J, Goff B, Telzer EH, Shapiro M, Hare TA, Bookheimer SY, Tottenham N (2013b) A developmental shift from positive to negative connectivity in human amygdala-prefrontal circuitry. J Neurosci 33:4584-4593. CrossRef Medline

Gee DG, Gabard-Durnam L, Telzer EH, Humphreys KL, Goff B, Shapiro M, Flannery J, Lumian DS, Fareri DS, Caldera C, Tottenham N (2014) Maternal buffering of human amygdala-prefrontal circuitry during childhood but not during adolescence. Psychol Sci 25:2067-2078. CrossRef Medline

Gee DG, Fetcho RN, Jing D, Li A, Glatt CE, Drysdale AT, Cohen AO, Dellarco DV, Yang RR, Dale AM, Jernigan TL, Lee FS, Casey BJ (2016) Individual differences in frontolimbic circuitry and anxiety emerge with adolescent changes in endocannabinoid signaling across species. Proc Natl Acad Sci U S A 113:4500-4505. CrossRef Medline

Ghetti S, Bunge SA (2012) Neural changes underlying the development of episodic memory during middle childhood. Dev Cogn Neurosci 2:381395. CrossRef Medline

Giedd JN (2004) Structural magnetic resonance imaging of the adolescent brain. Ann N Y Acad Sci 1021:77-85. CrossRef Medline

Giedd JN, Vaituzis AC, Hamburger SD, Lange N, Rajapakse JC, Kaysen D, Vauss YC, Rapoport JL (1996) Quantitative MRI of the temporal lobe, amygdala, and hippocampus in normal human development: ages 4-18 years. J Comp Neurol 366:223-230. CrossRef Medline

Giedd JN, Blumenthal J, Jeffries NO, Castellanos FX, Liu H, Zijdenbos A, Paus T, Evans AC, Rapoport JL (1999) Brain development during childhood and adolescence: a longitudinal MRI study. Nat Neurosci 2:861-863. CrossRef Medline

Gilmartin MR, McEchron MD (2005) Single neurons in the medial prefrontal cortex of the rat exhibit tonic and phasic coding during trace fear conditioning. Behav Neurosci 119:1496-1510. CrossRef Medline

Ginsburg GS, Becker-Haimes EM, Keeton C, Kendall PC, Iyengar S, Sakolsky D, Albano AM, Peris T, Compton SN, Piacentini J (2018) Results from the Child/Adolescent Anxiety Multimodal Extended Long-term Study (CAMELS): primary anxiety outcomes. J Am Acad Child Adolesc Psychiatry 57:471-480. CrossRef Medline

Glenn CR, Klein DN, Lissek S, Britton JC, Pine DS, Hajcak G (2012) The development of fear learning and generalization in 8-13 year-olds. Dev Psychobiol 54:675-684. CrossRef Medline

Goff B, Gee DG, Telzer EH, Humphreys KL, Gabard-Durnam L, Flannery J, Tottenham N (2013) Reduced nucleus accumbens reactivity and adolescent depression following early-life stress. Neuroscience 249:129-138. CrossRef Medline

Gogolla N, Caroni P, Lüthi A, Herry C (2009) Perineuronal nets protect fear memories from erasure. Science 325:1258-1261. CrossRef Medline

Gogtay N, Giedd JN, Lusk L, Hayashi KM, Greenstein D, Vaituzis AC, Nugent TF 3rd, Herman DH, Clasen LS, Toga AW, Rapoport JL, Thompson PM (2004) Dynamic mapping of human cortical development during childhood through early adulthood. Proc Natl Acad Sci U S A 101:8174-8179. CrossRef Medline

Goldapple K, Segal Z, Garson C, Lau M, Bieling P, Kennedy S, Mayberg H (2004) Modulation of cortical-limbic pathways in major depression: treatment-specific effects of cognitive behavior therapy. Arch Gen Psychiatry 61:34-41. CrossRef Medline

Goldin PR, Ziv M, Jazaieri H, Hahn K, Heimberg R, Gross JJ (2013) Impact of cognitive behavioral therapy for social anxiety disorder on the neural dynamics of cognitive reappraisal of negative self-beliefs: randomized clinical trial. JAMA Psychiatry 70:1048-1056. CrossRef Medline
Goldstein RZ, Volkow ND (2011) Dysfunction of the prefrontal cortex in addiction: neuroimaging findings and clinical implications. Nat Rev Neurosci 12:652-669. CrossRef Medline

Gomes FV, Rincón-Cortés M, Grace AA (2016) Adolescence as a period of vulnerability and intervention in schizophrenia: insights from the MAM model. Neurosci Biobehav Rev 70:260-270. CrossRef Medline

Goto Y, Grace AA (2005) Dopaminergic modulation of limbic and cortical drive of nucleus accumbens in goal-directed behavior. Nat Neurosci 8:805-812. CrossRef Medline

Gould E, Woolley CS, Cameron HA, Daniels DC, McEwen BS (1991a) Adrenal steroids regulate postnatal development of the rat dentate gyrus: II. Effects of glucocorticoids and mineralocorticoids on cell birth. J Comp Neurol 313:486-493. CrossRef Medline

Gould E, Woolley CS, McEwen BS (1991b) Adrenal steroids regulate postnatal development of the rat dentate gyrus: I. Effects of glucocorticoids on cell death. J Comp Neurol 313:479-485. CrossRef Medline

Gould E, Daniels DC, Cameron HA, McEwen BS (1992) Expression of adrenal steroid receptors by newly born cells and pyknotic cells in the dentate gyrus of the postnatal rat. Mol Cell Neurosci 3:44-48. CrossRef Medline

Gould E, McEwen BS, Tanapat P, Galea LA, Fuchs E (1997) Neurogenesis in the dentate gyrus of the adult tree shrew is regulated by psychosocial stress and NMDA receptor activation. J Neurosci 17:2492-2498. CrossRef Medline

Gould E, Tanapat P, McEwen BS, Flügge G, Fuchs E (1998) Proliferation of granule cell precursors in the dentate gyrus of adult monkeys is diminished by stress. Proc Natl Acad Sci U S A 95:3168-3171. CrossRef Medline

Graham AM, Fisher PA, Pfeifer JH (2013) What sleeping babies hear, what sleeping babies hear: a functional MRI study of interparental conflict and infants' emotion processing, a functional MRI study of interparental conflict and infants' emotion processing. Psychol Sci 24:782-789. CrossRef Medline

Graham AM, Buss C, Rasmussen JM, Rudolph MD, Demeter DV, Gilmore JH, Styner M, Entringer S, Wadhwa PD, Fair DA (2016) Implications of newborn amygdala connectivity for fear and cognitive development at 6-months-of-age. Dev Cogn Neurosci 18:12-25. CrossRef Medline

Grassi-Oliveira R, Honeycutt JA, Holland FH, Ganguly P, Brenhouse HC (2016) Cognitive impairment effects of early life stress in adolescents can be predicted with early biomarkers: impacts of sex, experience, and cytokines. Psychoneuroendocrinology 71:19-30. CrossRef Medline

Green JG, McLaughlin KA, Berglund PA, Gruber MJ, Sampson NA, Zaslavsky AM, Kessler RC (2010) Childhood adversities and adult psychiatric disorders in the national comorbidity survey replication: I. Associations with first onset of DSM-IV disorders. Arch Gen Psychiatry 67:113-123. CrossRef Medline

Gunnar MR, Donzella B (2002) Social regulation of the cortisol levels in early human development. Psychoneuroendocrinology 27:199-220. CrossRef Medline

Haber SN (2003) The primate basal ganglia: parallel and integrative networks. J Chem Neuroanat 26:317-330. CrossRef Medline

Haber SN, Knutson B (2010) The reward circuit: linking primate anatomy and human imaging. Neuropsychopharmacology 35:4-26. CrossRef Medline

Hanson JL, Adluru N, Chung MK, Alexander AL, Davidson RJ, Pollak SD (2013) Early neglect is associated with alterations in white matter integrity and cognitive functioning. Child Dev 84:1566-1578. CrossRef Medline

Hanson JL, Nacewicz BM, Sutterer MJ, Cayo AA, Schaefer SM, Rudolph KD, Shirtcliff EA, Pollak SD, Davidson RJ (2015) Behavioral problems after early life stress: contributions of the hippocampus and amygdala. Biol Psychiatry 77:314-323. CrossRef Medline

Hanson JL, Albert D, Iselin AM, Carré JM, Dodge KA, Hariri AR (2016) Cumulative stress in childhood is associated with blunted reward-related brain activity in adulthood. Soc Cogn Affect Neurosci 11:405-412. CrossRef Medline

Hanson JL, van den Bos W, Roeber BJ, Rudolph KD, Davidson RJ, Pollak SD (2017) Early adversity and learning: implications for typical and atypical behavioral development. J Child Psychol Psychiatry 58:770-778. CrossRef Medline

Hare TA, Tottenham N, Galvan A, Voss HU, Glover GH, Casey BJ (2008) Biological substrates of emotional reactivity and regulation in adoles- 
cence during an emotional go-nogo task. Biol Psychiatry 63:927-934. CrossRef Medline

Harms MB, Shannon Bowen KE, Hanson JL, Pollak SD (2018) Instrumental learning and cognitive flexibility processes are impaired in children exposed to early life stress. Dev Sci 21:e12596. CrossRef Medline

Hartley CA, Phelps EA (2010) Changing fear: the neurocircuitry of emotion regulation. Neuropsychopharmacology 35:136-146. CrossRef Medline

Hartley CA, Somerville LH (2015) The neuroscience of adolescent decisionmaking. Curr Opin Behav Sci 5:108-115. CrossRef Medline

Haycock JW, Becker L, Ang L, Furukawa Y, Hornykiewicz O, Kish SJ (2003) Marked disparity between age-related changes in dopamine and other presynaptic dopaminergic markers in human striatum. J Neurochem 87 : 574-585. CrossRef Medline

Hayne H (2004) Infant memory development: implications for childhood amnesia. Dev Rev 24:33-73. CrossRef

Hefner K, Holmes A (2007) Ontogeny of fear-, anxiety- and depressionrelated behavior across adolescence in C57BL/6J mice. Behav Brain Res 176:210-215. CrossRef Medline

Heim C, Nemeroff CB (2001) The role of childhood trauma in the neurobiology of mood and anxiety disorders: preclinical and clinical studies. Biol Psychiatry 49:1023-1039. CrossRef Medline

Heller AS (2016) Cortical-subcortical interactions in depression: from animal models to human psychopathology. Front Syst Neurosci 10:20. CrossRef Medline

Hensch TK (2005) Critical period plasticity in local cortical circuits. Nat Rev Neurosci 6:877-888. CrossRef Medline

Herringa RJ, Birn RM, Ruttle PL, Burghy CA, Stodola DE, Davidson RJ, Essex MJ (2013) Childhood maltreatment is associated with altered fear circuitry and increased internalizing symptoms by late adolescence. Proc Natl Acad Sci U S A 110:19119-19124. CrossRef Medline

Hodel AS, Hunt RH, Cowell RA, Van Den Heuvel SE, Gunnar MR, Thomas KM (2015) Duration of early adversity and structural brain development in post-institutionalized adolescents. Neuroimage 105:112-119. CrossRef Medline

Holland FH, Ganguly P, Potter DN, Chartoff EH, Brenhouse HC (2014) Early life stress disrupts social behavior and prefrontal cortex parvalbumin interneurons at an earlier time-point in females than in males. Neurosci Lett 566:131-136. CrossRef Medline

Honkaniemi J, Pelto-Huikko M, Rechardt L, Isola J, Lammi A, Fuxe K, Gustafsson JA, Wikström AC, Hökfelt T (1992) Colocalization of peptide and glucocorticoid receptor immunoreactivities in rat central amygdaloid nucleus. Neuroendocrinology 55:451-459. CrossRef Medline

Hostinar CE, Sullivan RM, Gunnar MR (2014) Psychobiological mechanisms underlying the social buffering of the hypothalamic-pituitaryadrenocortical axis: a review of animal models and human studies across development. Psychol Bull 140:256-282. CrossRef Medline

Hostinar CE, Johnson AE, Gunnar MR (2015) Parent support is less effective in buffering cortisol stress reactivity for adolescents compared to children. Dev Sci 18:281-297. CrossRef Medline

Hu H (2016) Reward and aversion. Annu Rev Neurosci 39:297-324. CrossRef Medline

Humphrey T (1968) The development of the human amygdala during early embryonic life. J Comp Neurol 132:135-165. CrossRef Medline

Ingram E, Fitzgerald HE (1974) Individual differences in infant orienting and autonomic conditioning. Dev Psychobiol 7:359-367. CrossRef Medline

Jablonski SA, Schiffino FL, Stanton ME (2012) Role of age, post-training consolidation, and conjunctive associations in the ontogeny of the context preexposure facilitation effect. Dev Psychobiol 54:714-722. CrossRef Medline

Jalbrzikowski M, Larsen B, Hallquist MN, Foran W, Calabro F, Luna B (2017) Development of white matter microstructure and intrinsic functional connectivity between the amygdala and ventromedial prefrontal cortex: associations with anxiety and depression. Biol Psychiatry 82:511521. CrossRef Medline

Johanson IB, Hall WG (1979) Appetitive learning in 1-day-old rat pups. Science 205:419-421. CrossRef Medline

Johnson CM, Loucks FA, Peckler H, Thomas AW, Janak PH, Wilbrecht L (2016) Long-range orbitofrontal and amygdala axons show divergent patterns of maturation in the frontal cortex across adolescence. Dev Cogn Neurosci 18:113-120. CrossRef Medline

Johnson DC, Casey BJ (2015a) Easy to remember, difficult to forget: the development of fear regulation. Dev Cogn Neurosci 11:42-55. CrossRef Medline

Johnson DC, Casey BJ (2015b) Extinction during memory reconsolidation blocks recovery of fear in adolescents. Sci Rep 5:8863. CrossRef Medline

Johnson FK, Delpech JC, Thompson GJ, Wei L, Hao J, Herman P, Hyder F, Kaffman A (2018) Amygdala hyper-connectivity in a mouse model of unpredictable early life stress. Transl Psychiatry 8:49. CrossRef Medline

Johnston JA, Wang F, Liu J, Blond BN, Wallace A, Liu J, Spencer L, Cox Lippard ET, Purves KL, Landeros-Weisenberger A, Hermes E, Pittman B, Zhang S, King R, Martin A, Oquendo MA, Blumberg HP (2017) Multimodal neuroimaging of frontolimbic structure and function associated with suicide attempts in adolescents and young adults with bipolar disorder. Am J Psychiatry 174:667-675. CrossRef Medline

Josselyn SA, Frankland PW (2012) Infantile amnesia: a neurogenic hypothesis. Learn Mem 19:423-433. CrossRef Medline

Jovanovic T, Nylocks KM, Gamwell KL, Smith A, Davis TA, Norrholm SD, Bradley B (2014) Development of fear acquisition and extinction in children: effects of age and anxiety. Neurobiol Learn Mem 113:135-142. CrossRef Medline

Kaiser RH, Clegg R, Goer F, Pechtel P, Beltzer M, Vitaliano G, Olson DP, Teicher MH, Pizzagalli DA (2018) Childhood stress, grown-up brain networks: corticolimbic correlates of threat-related early life stress and adult stress response. Psychol Med 48:1157-1166. CrossRef Medline

Kalinichev M, Easterling KW, Plotsky PM, Holtzman SG (2002) Longlasting changes in stress-induced corticosterone response and anxiety-like behaviors as a consequence of neonatal maternal separation in LongEvans rats. Pharmacol Biochem Behav 73:131-140. CrossRef Medline

Kamkar NH, Lewis DJ, van den Bos W, Morton JB (2017) Ventral striatal activity links adversity and reward processing in children. Dev Cogn Neurosci 26:20-27. CrossRef Medline

Keren H, Chen G, Benson B, Ernst M, Leibenluft E, Fox NA, Pine DS, Stringaris A (2018) Is the encoding of reward prediction error reliable during development? Neuroimage 178:266-276. CrossRef Medline

Kessler RC, McLaughlin KA, Green JG, Gruber MJ, Sampson NA, Zaslavsky AM, Aguilar-Gaxiola S, Alhamzawi AO, Alonso J, Angermeyer M, Benjet C, Bromet E, Chatterji S, de Girolamo G, Demyttenaere K, Fayyad J, Florescu S, Gal G, Gureje O, Haro JM, et al. (2010) Childhood adversities and adult psychopathology in the WHO world mental health surveys. Br J Psychiatry 197:378-385. CrossRef Medline

Kessler RC, Berglund P, Demler O, Jin R, Merikangas KR, Walters EE (2005) Lifetime prevalence and age-of-onset distributions of DSM-IV disorders in the national comorbidity survey replication. Arch Gen Psychiatry 62: 593-602. CrossRef Medline

Kessler RC, Amminger GP, Aguilar-Gaxiola S, Alonso J, Lee S, Ustün TB (2007) Age of onset of mental disorders: a review of recent literature. Curr Opin Psychiatry 20:359-364. CrossRef Medline

Kikusui T, Mori Y (2009) Behavioural and neurochemical consequences of early weaning in rodents. J Neuroendocrinol 21:427-431. CrossRef Medline

Kim JH, Richardson R (2007) A developmental dissociation of context and GABA effects on extinguished fear in rats. Behav Neurosci 121:131-139. CrossRef Medline

Kim JH, Hamlin AS, Richardson R (2009) Fear extinction across development: the involvement of the medial prefrontal cortex as assessed by temporary inactivation and immunohistochemistry. J Neurosci 29: 10802-10808. CrossRef Medline

Kim JH, Li S, Richardson R (2011) Immunohistochemical analyses of longterm extinction of conditioned fear in adolescent rats. Cereb Cortex 21: 530-538. CrossRef Medline

Kok R, Thijssen S, Bakermans-Kranenburg MJ, Jaddoe VW, Verhulst FC, White T, van IJzendoorn MH, Tiemeier H (2015) Normal variation in early parental sensitivity predicts child structural brain development. J Am Acad Child Adolesc Psychiatry 54:824-831.e1. CrossRef Medline

Krugers HJ, Arp JM, Xiong H, Kanatsou S, Lesuis SL, Korosi A, Joels M, Lucassen PJ (2017) Early life adversity: lasting consequences for emotional learning. Neurobiol Stress 6:14-21. CrossRef Medline

Lammel S, Lim BK, Malenka RC (2014) Reward and aversion in a heterogeneous midbrain dopamine system. Neuropharmacology 76:351-359. CrossRef Medline

Landers MS, Sullivan RM (2012) The development and neurobiology of infant attachment and fear. Dev Neurosci 34:101-114. CrossRef Medline

Lau JY, Britton JC, Nelson EE, Angold A, Ernst M, Goldwin M, Grillon C, Leibenluft E, Lissek S, Norcross M, Shiffrin N, Pine DS (2011) Distinct 
neural signatures of threat learning in adolescents and adults. Proc Natl Acad Sci U S A 108:4500-4505. CrossRef Medline

Laube C, van den Bos W (2016) Hormones and affect in adolescent decision making. In: Recent developments in neuroscience research on human motivation, pp 259-281 Advances in motivation and achievement. Bingley, UK: Emerald.

Laube C, Suleiman AB, Johnson M, Dahl RE, van den Bos W (2017) Dissociable effects of age and testosterone on adolescent impatience. Psychoneuroendocrinology 80:162-169. CrossRef Medline

Laviola G, Macrì S, Morley-Fletcher S, Adriani W (2003) Risk-taking behavior in adolescent mice: psychobiological determinants and early epigenetic influence. Neurosci Biobehav Rev 27:19-31. CrossRef Medline

Lawler JM, Hostinar CE, Mliner SB, Gunnar MR (2014) Disinhibited social engagement in postinstitutionalized children: differentiating normal from atypical behavior. Dev Psychopathol 26:451-464. CrossRef Medline

Lebel C, Gee M, Camicioli R, Wieler M, Martin W, Beaulieu C (2012) Diffusion tensor imaging of white matter tract evolution over the lifespan. Neuroimage 60:340-352. CrossRef Medline

LeDoux J, Daw ND (2018) Surviving threats: neural circuit and computational implications of a new taxonomy of defensive behaviour. Nat Rev Neurosci 19:269-282. CrossRef Medline

Lee FS, Heimer H, Giedd JN, Lein ES, Sestan N, Weinberger DR, Casey BJ (2014) Mental health. adolescent mental health: opportunity and obligation. Science 346:547-549. CrossRef Medline

Li S, Kim JH, Richardson R (2012) Updating memories: changing the involvement of the prelimbic cortex in the expression of an infant fear memory. Neuroscience 222:316-325. CrossRef Medline

Li S, Callaghan BL, Richardson R (2014) Infantile amnesia: forgotten but not gone. Learn Mem 21:135-139. CrossRef Medline

Liberzon I, Ma ST, Okada G, Ho SS, Swain JE, Evans GW (2015) Childhood poverty and recruitment of adult emotion regulatory neurocircuitry. Soc Cogn Affect Neurosci 10:1596-1606. CrossRef Medline

Liston C, Gan WB (2011) Glucocorticoids are critical regulators of dendritic spine development and plasticity in vivo. Proc Natl Acad Sci U S A 108: 16074-16079. CrossRef Medline

Loman MM, Wiik KL, Frenn KA, Pollak SD, Gunnar MR (2009) Postinstitutionalized children's development: growth, cognitive, and language outcomes. J Dev Behav Pediatr 30:426-434. CrossRef Medline

Luby J, Belden A, Botteron K, Marrus N, Harms MP, Babb C, Nishino T, Barch D (2013) The effects of poverty on childhood brain development: the mediating effect of caregiving and stressful life events. JAMA Pediatr 167:1135-1142. CrossRef Medline

Luna B, Marek S, Larsen B, Tervo-Clemmens B, Chahal R (2015) An integrative model of the maturation of cognitive control. Annu Rev Neurosci 38:151-170. CrossRef Medline

Lupien SJ, McEwen BS, Gunnar MR, Heim C (2009) Effects of stress throughout the lifespan on the brain, behaviour and cognition. Nat Rev Neurosci 10:434-445. CrossRef Medline

Magariños AM, Orchinik M, McEwen BS (1998) Morphological changes in the hippocampal CA3 region induced by non-invasive glucocorticoid administration: a paradox. Brain Res 809:314-318. CrossRef Medline

Malter Cohen M, Jing D, Yang RR, Tottenham N, Lee FS, Casey BJ (2013) Early-life stress has persistent effects on amygdala function and development in mice and humans. Proc Natl Acad Sci U S A 110:18274-18278. CrossRef Medline

Maren S, Quirk GJ (2004) Neuronal signalling of fear memory. Nat Rev Neurosci 5:844-852. CrossRef Medline

Maren S, Phan KL, Liberzon I (2013) The contextual brain: implications for fear conditioning, extinction and psychopathology. Nat Rev Neurosci 14:417-428. CrossRef Medline

Matthews M, Bondi C, Torres G, Moghaddam B (2013) Reduced presynaptic dopamine activity in adolescent dorsal striatum. Neuropsychopharmacology 38:1344-1351. CrossRef Medline

McCallum J, Kim JH, Richardson R (2010) Impaired extinction retention in adolescent rats: effects of D-cycloserine. Neuropsychopharmacology 35: 2134-2142. CrossRef Medline

McDermott JM, Westerlund A, Zeanah CH, Nelson CA, Fox NA (2012) Early adversity and neural correlates of executive function: implications for academic adjustment. Dev Cogn Neurosci 2:S59-S66. CrossRef Medline

McEwen BS (2003) Early life influences on life-long patterns of behavior and health. Ment Retard Dev Disabil Res Rev 9:149-154. CrossRef Medline

McLaughlin KA, Sheridan MA, Tibu F, Fox NA, Zeanah CH, Nelson CA 3rd (2015) Causal effects of the early caregiving environment on development of stress response systems in children. Proc Natl Acad Sci U S A 112:5637-5642. CrossRef Medline

McLaughlin KA, Sheridan MA, Gold AL, Duys A, Lambert HK, Peverill M, Heleniak C, Shechner T, Wojcieszak Z, Pine DS (2016) Maltreatment exposure, brain structure, and fear conditioning in children and adolescents. Neuropsychopharmacology 41:1956-1964. CrossRef Medline

Mehta MA, Golembo NI, Nosarti C, Colvert E, Mota A, Williams SC, Rutter M, Sonuga-Barke EJ (2009) Amygdala, hippocampal and corpus callosum size following severe early institutional deprivation: the English and Romanian Adoptees Study pilot. J Child Psychol Psychiatry 50:943-951. CrossRef Medline

Mehta MA, Gore-Langton E, Golembo N, Colvert E, Williams SC, SonugaBarke E (2010) Hyporesponsive reward anticipation in the basal ganglia following severe institutional deprivation early in life. J Cogn Neurosci 22:2316-2325. CrossRef Medline

Michalska KJ, Shechner T, Hong M, Britton JC, Leibenluft E, Pine DS, Fox NA (2016) A developmental analysis of threat/safety learning and extinction recall during middle childhood. J Exp Child Psychol 146:95-105. CrossRef Medline

Milad MR, Quirk GJ (2012) Fear extinction as a model for translational neuroscience: ten years of progress. Annu Rev Psychol 63:129-151. CrossRef Medline

Monk CS (2008) The development of emotion-related neural circuitry in health and psychopathology. Dev Psychopathol 20:1231-1250. CrossRef Medline

Moriceau S, Sullivan RM (2006) Maternal presence serves as a switch between learning fear and attraction in infancy. Nat Neurosci 9:1004-1006. CrossRef Medline

Moriceau S, Roth TL, Okotoghaide T, Sullivan RM (2004) Corticosterone controls the developmental emergence of fear and amygdala function to predator odors in infant rat pups. Int J Dev Neurosci 22:415-422. CrossRef Medline

Moriceau S, Wilson DA, Levine S, Sullivan RM (2006) Dual circuitry for odor-shock conditioning during infancy: corticosterone switches between fear and attraction via amygdala. J Neurosci 26:6737-6748. CrossRef Medline

Moriceau S, Raineki C, Holman JD, Holman JG, Sullivan RM (2009) Enduring neurobehavioral effects of early life trauma mediated through learning and corticosterone suppression. Front Behav Neurosci 3:22. CrossRef Medline

Morrow MC, Boring FW, Keough TE, Haesly RR (1969) Differential GSR conditioning as a function of age. Dev Psychol 1:299-302. CrossRef

Moscarello JM, LeDoux JE (2013) Active avoidance learning requires prefrontal suppression of amygdala-mediated defensive reactions. J Neurosci 33:3815-3823. CrossRef Medline

Muhammad A, Carroll C, Kolb B (2012) Stress during development alters dendritic morphology in the nucleus accumbens and prefrontal cortex. Neuroscience 216:103-109. CrossRef Medline

Mullally SL, Maguire EA (2014) Learning to remember: the early ontogeny of episodic memory. Dev Cogn Neurosci 9:12-29. CrossRef Medline

Murty VP, Calabro F, Luna B (2016) The role of experience in adolescent cognitive development: integration of executive, memory, and mesolimbic systems. Neurosci Biobehav Rev 70:46-58. CrossRef Medline

Namburi P, Beyeler A, Yorozu S, Calhoon GG, Halbert SA, Wichmann R, Holden SS, Mertens KL, Anahtar M, Felix-Ortiz AC, Wickersham IR, Gray JM, Tye KM (2015) A circuit mechanism for differentiating positive and negative associations. Nature 520:675-678. CrossRef Medline

Nelson CA 3rd, Zeanah CH, Fox NA, Marshall PJ, Smyke AT, Guthrie D (2007) Cognitive recovery in socially deprived young children: the Bucharest Early Intervention Project. Science 318:1937-1940. CrossRef Medline

O’Donnell P (2010) Adolescent maturation of cortical dopamine. Neurotox Res 18:306-312. CrossRef Medline

Ono M, Kikusui T, Sasaki N, Ichikawa M, Mori Y, Murakami-Murofushi K (2008) Early weaning induces anxiety and precocious myelination in the anterior part of the basolateral amygdala of male BALB/c mice. Neuroscience 156:1103-1110. CrossRef Medline

Op de Macks ZA, Gunther Moor B, Overgaauw S, Güroğlu B, Dahl RE, Crone 
EA (2011) Testosterone levels correspond with increased ventral striatum activation in response to monetary rewards in adolescents. Dev Cogn Neurosci 1:506-516. CrossRef Medline

Palminteri S, Kilford EJ, Coricelli G, Blakemore SJ (2016) The computational development of reinforcement learning during adolescence. PLOS Comput Biol 12:e1004953. CrossRef Medline

Pattwell SS, Bath KG, Casey BJ, Ninan I, Lee FS (2011) Selective earlyacquired fear memories undergo temporary suppression during adolescence. Proc Natl Acad Sci U S A 108:1182-1187. CrossRef Medline

Pattwell SS, Duhoux S, Hartley CA, Johnson DC, Jing D, Elliott MD, Ruberry EJ, Powers A, Mehta N, Yang RR, Soliman F, Glatt CE, Casey BJ, Ninan I, Lee FS (2012) Altered fear learning across development in both mouse and human. Proc Natl Acad Sci U S A 109:16318-16323. CrossRef Medline

Pattwell SS, Liston C, Jing D, Ninan I, Yang RR, Witztum J, Murdock MH, Dincheva I, Bath KG, Casey BJ, Deisseroth K, Lee FS (2016) Dynamic changes in neural circuitry during adolescence are associated with persistent attenuation of fear memories. Nat Commun 7:11475. CrossRef Medline

Paus T, Keshavan M, Giedd JN (2008) Why do many psychiatric disorders emerge during adolescence? Nat Rev Neurosci 9:947-957. CrossRef Medline

Payne C, Machado CJ, Bliwise NG, Bachevalier J (2010) Maturation of the hippocampal formation and amygdala in Macaca mulatta: a volumetric magnetic resonance imaging study. Hippocampus 20:922-935. CrossRef Medline

Perlman SB, Pelphrey KA (2011) Developing connections for affective regulation: age-related changes in emotional brain connectivity. J Exp Child Psychol 108:607-620. CrossRef Medline

Peters S, Crone EA (2017) Increased striatal activity in adolescence benefits learning. Nat Commun 8:1983. CrossRef Medline

Phelps EA, LeDoux JE (2005) Contributions of the amygdala to emotion processing: from animal models to human behavior. Neuron 48:175-187. CrossRef Medline

Philpot RM, Wecker L, Kirstein CL (2009) Repeated ethanol exposure during adolescence alters the developmental trajectory of dopaminergic output from the nucleus accumbens septi. Int J Dev Neurosci 27:805-815. CrossRef Medline

Plotsky PM, Thrivikraman KV, Nemeroff CB, Caldji C, Sharma S, Meaney MJ (2005) Long-term consequences of neonatal rearing on central corticotropin-releasing factor systems in adult male rat offspring. Neuropsychopharmacology 30:2192-2204. CrossRef Medline

Powell SB, Khan A, Young JW, Scott CN, Buell MR, Caldwell S, Tsan E, de Jong LA, Acheson DT, Lucero J, Geyer MA, Behrens MM (2015) Early adolescent emergence of reversal learning impairments in isolationreared rats. Dev Neurosci 37:253-262. CrossRef Medline

Purves-Tyson TD, Owens SJ, Double KL, Desai R, Handelsman DJ, Weickert CS (2014) Testosterone induces molecular changes in dopamine signaling pathway molecules in the adolescent male rat nigrostriatal pathway. PLoS One 9:e91151. CrossRef Medline

Qin S, Young CB, Supekar K, Uddin LQ, Menon V (2012) Immature integration and segregation of emotion-related brain circuitry in young children. Proc Natl Acad Sci U S A 109:7941-7946. CrossRef Medline

Quirk GJ, Mueller D (2008) Neural mechanisms of extinction learning and retrieval. Neuropsychopharmacology 33:56-72. CrossRef Medline

Raineki C, Holman PJ, Debiec J, Bugg M, Beasley A, Sullivan RM (2010) Functional emergence of the hippocampus in context fear learning in infant rats. Hippocampus 20:1037-1046. CrossRef Medline

Rauch SL, Shin LM, Wright CI (2003) Neuroimaging studies of amygdala function in anxiety disorders. Ann N Y Acad Sci 985:389-410. CrossRef Medline

Ressler KJ, Mayberg HS (2007) Targeting abnormal neural circuits in mood and anxiety disorders: from the laboratory to the clinic. Nat Neurosci 10:1116-1124. CrossRef Medline

Richards M, Wadsworth ME (2004) Long term effects of early adversity on cognitive function. Arch Dis Child 89:922-927. CrossRef Medline

Rogers CE, Sylvester CM, Mintz C, Kenley JK, Shimony JS, Barch DM, Smyser CD (2017) Neonatal amygdala functional connectivity at rest in healthy and preterm infants and early internalizing symptoms. J Am Acad Child Adolesc Psychiatry 56:157-166. CrossRef Medline

Romeo RD, Mueller A, Sisti HM, Ogawa S, McEwen BS, Brake WG (2003) Anxiety and fear behaviors in adult male and female C57BL/6 mice are modulated by maternal separation. Horm Behav 43:561-567. CrossRef Medline

Romeo RD, Bellani R, Karatsoreos IN, Chhua N, Vernov M, Conrad CD, McEwen BS (2006) Stress history and pubertal development interact to shape hypothalamic-pituitary-adrenal axis plasticity. Endocrinology 147: 1664-1674. CrossRef Medline

Rudy JW (1992) Development of learning: from elemental to configural associative networks. Adv Infancy Res 7:247-289.

Rudy JW (1993) Contextual conditioning and auditory cue conditioning dissociate during development. Behav Neurosci 107:887-891. CrossRef Medline

Rudy JW, Cheatle MD (1977) Odor-aversion learning in neonatal rats. Science 198:845-846. CrossRef Medline

Rutter M, O'Connor TG (2004) Are there biological programming effects for psychological development? Findings from a study of Romanian adoptees. Dev Psychol 40:81-94. CrossRef Medline

Ruttle PL, Shirtcliff EA, Armstrong JM, Klein MH, Essex MJ (2015) Neuroendocrine coupling across adolescence and the longitudinal influence of early life stress. Dev Psychobiol 57:688-704. CrossRef Medline

Sabatini MJ, Ebert P, Lewis DA, Levitt P, Cameron JL, Mirnics K (2007) Amygdala gene expression correlates of social behavior in monkeys experiencing maternal separation. J Neurosci 27:3295-3304. CrossRef Medline

Salamone JD, Correa M (2012) The mysterious motivational functions of mesolimbic dopamine. Neuron 76:470-485. CrossRef Medline

Sánchez MM, Ladd CO, Plotsky PM (2001) Early adverse experience as a developmental risk factor for later psychopathology: evidence from rodent and primate models. Dev Psychopathol 13:419-449. CrossRef Medline

Saul ML, Helmreich DL, Callahan LM, Fudge JL (2014) Differences in amygdala cell proliferation between adolescent and young adult rats. Dev Psychobiol 56:517-528. CrossRef Medline

Schiffino FL, Murawski NJ, Rosen JB, Stanton ME (2011) Ontogeny and neural substrates of the context preexposure facilitation effect. Neurobiol Learn Mem 95:190-198. CrossRef Medline

Schultz W (2015) Neuronal reward and decision signals: from theories to data. Physiol Rev 95:853-951. CrossRef Medline

Schultz W, Dayan P, Montague PR (1997) A neural substrate of prediction and reward. Science 275:1593-1599. CrossRef Medline

Seamans JK, Yang CR (2004) The principal features and mechanisms of dopamine modulation in the prefrontal cortex. Prog Neurobiol 74:1-58. CrossRef Medline

Seltzer LJ, Prososki AR, Ziegler TE, Pollak SD (2012) Instant messages vs. speech: hormones and why we still need to hear each other. Evol Hum Behav 33:42-45. CrossRef Medline

Sesack SR, Grace AA (2010) Cortico-basal ganglia reward network: microcircuitry. Neuropsychopharmacology 35:27-47. CrossRef Medline

Sheridan MA, McLaughlin KA (2014) Dimensions of early experience and neural development: deprivation and threat. Trends Cogn Sci 18:580585. CrossRef Medline

Sheridan MA, McLaughlin KA, Winter W, Fox N, Zeanah C, Nelson CA (2018) Early deprivation disruption of associative learning is a developmental pathway to depression and social problems. Nat Commun 9:2216. CrossRef Medline

Shohamy D, Adcock RA (2010) Dopamine and adaptive memory. Trends Cogn Sci 14:464-472. CrossRef Medline

Shonkoff JP, Garner AS (2012) The lifelong effects of early childhood adversity and toxic stress. Pediatrics 129:e232-e246. CrossRef Medline

Sierra-Mercado D, Padilla-Coreano N, Quirk GJ (2011) Dissociable roles of prelimbic and infralimbic cortices, ventral hippocampus, and basolateral amygdala in the expression and extinction of conditioned fear. Neuropsychopharmacology 36:529-538. CrossRef Medline

Silberg J, Pickles A, Rutter M, Hewitt J, Simonoff E, Maes H, Carbonneau R, Murrelle L, Foley D, Eaves L (1999) The influence of genetic factors and life stress on depression among adolescent girls. Arch Gen Psychiatry 56:225-232. CrossRef Medline

Silverman MH, Jedd K, Luciana M (2015) Neural networks involved in adolescent reward processing: an activation likelihood estimation metaanalysis of functional neuroimaging studies. Neuroimage 122:427-439. CrossRef Medline

Silvers JA, Shu J, Hubbard AD, Weber J, Ochsner KN (2015) Concurrent 
and lasting effects of emotion regulation on amygdala response in adolescence and young adulthood. Dev Sci 18:771-784. CrossRef Medline

Silvers JA, Lumian DS, Gabard-Durnam L, Gee DG, Goff B, Fareri DS, Caldera C, Flannery J, Telzer EH, Humphreys KL, Tottenham N (2016) Previous institutionalization is followed by broader amygdalahippocampal-PFC network connectivity during aversive learning in human development. J Neurosci 36:6420-6430. CrossRef Medline

Simmonds DJ, Hallquist MN, Asato M, Luna B (2014) Developmental stages and sex differences of white matter and behavioral development through adolescence: a longitudinal diffusion tensor imaging (DTI) study. Neuroimage 92:356-368. CrossRef Medline

Sinclair D, Purves-Tyson TD, Allen KM, Weickert CS (2014) Impacts of stress and sex hormones on dopamine neurotransmission in the adolescent brain. Psychopharmacology (Berl) 231:1581-1599. CrossRef Medline

Somerville LH, Haddara N, Sasse SF, Skwara AC, Moran JM, Figner B (2018) Dissecting "peer presence" and "decisions" to deepen understanding of peer influence on adolescent risky choice. Child Dev. Advance online publication. Retrieved Apr. 27, 2018. doi: 10.1111/cdev.13081. CrossRef Medline

Sotres-Bayon F, Quirk GJ (2010) Prefrontal control of fear: more than just extinction. Curr Opin Neurobiol 20:231-235. CrossRef Medline

Spear LP (2013) Adolescent neurodevelopment. J Adolesc Health 52:S7S13. CrossRef Medline

Stamford JA (1989) Development and ageing of the rat nigrostriatal dopamine system studied with fast cyclic voltammetry. J Neurochem 52:15821589. CrossRef Medline

Stanton ME, Wallstrom J, Levine S (1987) Maternal contact inhibits pituitary-adrenal stress responses in preweanling rats. Dev Psychobiol 20:131-145. CrossRef Medline

Stehouwer DJ, Campbell BA (1978) Habituation of the forelimbwithdrawal response in neonatal rats. J Exp Psychol Anim Behav Process 4:104-119. CrossRef Medline

Stuber GD, Sparta DR, Stamatakis AM, van Leeuwen WA, Hardjoprajitno JE, Cho S, Tye KM, Kempadoo KA, Zhang F, Deisseroth K, Bonci A (2011) Excitatory transmission from the amygdala to nucleus accumbens facilitates reward seeking. Nature 475:377-380. CrossRef Medline

Suchecki D, Rosenfeld P, Levine S (1993) Maternal regulation of the hypothalamic-pituitary-adrenal axis in the infant rat: the roles of feeding and stroking. Dev Brain Res 75:185-192. CrossRef Medline

Sullivan RM, Landers M, Yeaman B, Wilson DA (2000) Good memories of bad events in infancy. Nature 407:38-39. CrossRef Medline

Swartz JR, Carrasco M, Wiggins JL, Thomason ME, Monk CS (2014) Agerelated changes in the structure and function of prefrontal cortexamygdala circuitry in children and adolescents: a multi-modal imaging approach. Neuroimage 86:212-220. CrossRef Medline

Tanapat P, Galea LA, Gould E (1998) Stress inhibits the proliferation of granule cell precursors in the developing dentate gyrus. Int J Dev Neurosci 16:235-239. CrossRef Medline

Tarazi FI, Tomasini EC, Baldessarini RJ (1998) Postnatal development of dopamine and serotonin transporters in rat caudate-putamen and nucleus accumbens septi. Neurosci Lett 254:21-24. CrossRef Medline

Taylor SF, Kang J, Brege IS, Tso IF, Hosanagar A, Johnson TD (2012) Metaanalysis of functional neuroimaging studies of emotion perception and experience in schizophrenia. Biol Psychiatry 71:136-145. CrossRef Medline

Teicher MH, Andersen SL, Hostetter JC Jr (1995) Evidence for dopamine receptor pruning between adolescence and adulthood in striatum but not nucleus accumbens. Brain Res Dev Brain Res 89:167-172. CrossRef Medline

Teicher MH, Samson JA, Anderson CM, Ohashi K (2016) The effects of childhood maltreatment on brain structure, function and connectivity. Nat Rev Neurosci 17:652-666. CrossRef Medline

Thomas AW, Caporale N, Wu C, Wilbrecht L (2016) Early maternal separation impacts cognitive flexibility at the age of first independence in mice. Dev Cogn Neurosci 18:49-56. CrossRef Medline

Thomason ME, Marusak HA, Tocco MA, Vila AM, McGarragle O, Rosenberg DR (2015) Altered amygdala connectivity in urban youth exposed to trauma. Soc Cogn Affect Neurosci 10:1460-1468. CrossRef Medline

Thompson JV, Sullivan RM, Wilson DA (2008) Developmental emergence of fear learning corresponds with changes in amygdala synaptic plasticity. Brain Res 1200:58-65. CrossRef Medline

Tottenham N (2012) Human amygdala development in the absence of species-expected caregiving. Dev Psychobiol 54:598-611. CrossRef Medline

Tottenham N, Sheridan MA (2009) A review of adversity, the amygdala and the hippocampus: a consideration of developmental timing. Front Hum Neurosci 3:68. CrossRef Medline

Tottenham N, Hare TA, Quinn BT, McCarry TW, Nurse M, Gilhooly T, Millner A, Galvan A, Davidson MC, Eigsti IM, Thomas KM, Freed PJ, Booma ES, Gunnar MR, Altemus M, Aronson J, Casey BJ (2010) Prolonged institutional rearing is associated with atypically larger amygdala volume and difficulties in emotion regulation. Dev Sci 13:46-61. CrossRef Medline

Tottenham N, Hare TA, Millner A, Gilhooly T, Zevin JD, Casey BJ (2011) Elevated amygdala response to faces following early deprivation. Dev Sci 14:190-204. CrossRef Medline

Ulfig N, Setzer M, Bohl J (2003) Ontogeny of the human amygdala. Ann N Y Acad Sci 985:22-33. CrossRef Medline

van den Bos W, Cohen MX, Kahnt T, Crone EA (2012) Striatum-medial prefrontal cortex connectivity predicts developmental changes in reinforcement learning. Cereb Cortex 22:1247-1255. CrossRef Medline

van den Bos W, Rodriguez CA, Schweitzer JB, McClure SM (2015) Adolescent impatience decreases with increased frontostriatal connectivity. Proc Natl Acad Sci U S A 112:E3765-E3774. CrossRef Medline

van Harmelen AL, van Tol MJ, van der Wee NJ, Veltman DJ, Aleman A, Spinhoven P, van Buchem MA, Zitman FG, Penninx BW, Elzinga BM (2010) Reduced medial prefrontal cortex volume in adults reporting childhood emotional maltreatment. Biol Psychiatry 68:832-838. CrossRef Medline

van Harmelen AL, van Tol MJ, Dalgleish T, van der Wee NJ, Veltman DJ, Aleman A, Spinhoven P, Penninx BW, Elzinga BM (2014) Hypoactive medial prefrontal cortex functioning in adults reporting childhood emotional maltreatment. Soc Cogn Affect Neurosci 9:2026-2033. CrossRef Medline

Vink M, Derks JM, Hoogendam JM, Hillegers M, Kahn RS (2014) Functional differences in emotion processing during adolescence and early adulthood. Neuroimage 91:70-76. CrossRef Medline

Vythilingam M, Heim C, Newport J, Miller AH, Anderson E, Bronen R, Brummer M, Staib L, Vermetten E, Charney DS, Nemeroff CB, Bremner JD (2002) Childhood trauma associated with smaller hippocampal volume in women with major depression. Am J Psychiatry 159:2072-2080. CrossRef Medline

Walkup JT, Albano AM, Piacentini J, Birmaher B, Compton SN, Sherrill JT, Ginsburg GS, Rynn MA, McCracken J, Waslick B, Iyengar S, March JS, Kendall PC (2008) Cognitive behavioral therapy, sertraline, or a combination in childhood anxiety. N Engl J Med 359:2753-2766. CrossRef Medline

Wang Q, Verweij EW, Krugers HJ, Joels M, Swaab DF, Lucassen PJ (2014) Distribution of the glucocorticoid receptor in the human amygdala; changes in mood disorder patients. Brain Struct Funct 219:1615-1626. CrossRef Medline

Watanabe Y, Gould E, McEwen BS (1992) Stress induces atrophy of apical dendrites of hippocampal CA3 pyramidal neurons. Brain Res 588:341345. CrossRef Medline

Wickens DD, Wickens C (1940) A study of conditioning in the neonate. J Exp Psychol 26:94-102. CrossRef

Woolley CS, Gould E, McEwen BS (1990) Exposure to excess glucocorticoids alters dendritic morphology of adult hippocampal pyramidal neurons. Brain Res 531:225-231. CrossRef Medline

Yan CG, Rincón-Cortés M, Raineki C, Sarro E, Colcombe S, Guilfoyle DN, Yang Z, Gerum S, Biswal BB, Milham MP, Sullivan RM, Castellanos FX (2017) Aberrant development of intrinsic brain activity in a rat model of caregiver maltreatment of offspring. Transl Psychiatry 7:e1005. CrossRef Medline

Yang XD, Liao XM, Uribe-Mariño A, Liu R, Xie XM, Jia J, Su YA, Li JT, Schmidt MV, Wang XD, Si TM (2015) Stress during a critical postnatal period induces region-specific structural abnormalities and dysfunction of the prefrontal cortex via CRF1. Neuropsychopharmacology 40:12031215. CrossRef Medline

Yap CS, Richardson R (2007) Extinction in the developing rat: an examination of renewal effects. Dev Psychobiol 49:565-575. CrossRef Medline

Zeanah CH, Egger HL, Smyke AT, Nelson CA, Fox NA, Marshall PJ, Guthrie D (2009) Institutional rearing and psychiatric disorders in Romanian preschool children. Am J Psychiatry 166:777-785. CrossRef Medline 